\title{
Modeling spatiotemporal dynamics of global wetlands: comprehensive evaluation of a new sub-grid TOPMODEL parameterization and uncertainties
}

\author{
Zhen Zhang ${ }^{1,2,3}$, Niklaus E. Zimmermann ${ }^{1,4}$, Jed O. Kaplan ${ }^{5}$, and Benjamin Poulter ${ }^{2}$ \\ ${ }^{1}$ Dynamic Macroecology, Swiss Federal Research Institute WSL, Zürcherstrasse 111, 8903 Birmensdorf, Switzerland \\ ${ }^{2}$ Institute on Ecosystems and Department of Ecology, Montana State University, Bozeman, MT 59717, USA \\ ${ }^{3}$ Cold and Arid Regions Environmental and Engineering Research Institute, Chinese Academy of Sciences, Lanzhou, 730000, \\ Gansu, China \\ ${ }^{4}$ Department of Environmental Systems Science, Swiss Federal Institute of Technology ETH, 8092 Zürich, Switzerland \\ ${ }^{5}$ Institute of Earth Surface Dynamics, University of Lausanne, 1015 Lausanne, Switzerland
}

Correspondence to: Zhen Zhang (yuisheng@gmail.com)

Received: 17 August 2015 - Published in Biogeosciences Discuss.: 10 November 2015

Revised: 13 February 2016 - Accepted: 16 February 2016 - Published: 4 March 2016

\begin{abstract}
Simulations of the spatiotemporal dynamics of wetlands are key to understanding the role of wetland biogeochemistry under past and future climate. Hydrologic inundation models, such as the TOPography-based hydrological model (TOPMODEL), are based on a fundamental parameter known as the compound topographic index (CTI) and offer a computationally cost-efficient approach to simulate wetland dynamics at global scales. However, there remains a large discrepancy in the implementations of TOPMODEL in landsurface models (LSMs) and thus their performance against observations. This study describes new improvements to TOPMODEL implementation and estimates of global wetland dynamics using the LPJ-wsl (Lund-Potsdam-Jena Wald Schnee und Landschaft version) Dynamic Global Vegetation Model (DGVM) and quantifies uncertainties by comparing three digital elevation model (DEM) products (HYDRO1k, GMTED, and HydroSHEDS) at different spatial resolution and accuracy on simulated inundation dynamics. In addition, we found that calibrating TOPMODEL with a benchmark wetland data set can help to successfully delineate the seasonal and interannual variation of wetlands, as well as improve the spatial distribution of wetlands to be consistent with inventories. The HydroSHEDS DEM, using a riverbasin scheme for aggregating the CTI, shows the best accuracy for capturing the spatiotemporal dynamics of wetlands among the three DEM products. The estimate of global wet-
\end{abstract}

land potential/maximum is $\sim 10.3 \mathrm{Mkm}^{2}\left(10^{6} \mathrm{~km}^{2}\right)$, with a mean annual maximum of $\sim 5.17 \mathrm{Mkm}^{2}$ for $1980-2010$. When integrated with wetland methane emission submodule, the uncertainty of global annual $\mathrm{CH}_{4}$ emissions from topography inputs is estimated to be $29.0 \mathrm{Tg} \mathrm{yr}^{-1}$. This study demonstrates the feasibility of TOPMODEL to capture spatial heterogeneity of inundation at a large scale and highlights the significance of correcting maximum wetland extent to improve modeling of interannual variations in wetland area. It additionally highlights the importance of an adequate investigation of topographic indices for simulating global wetlands and shows the opportunity to converge wetland estimates across LSMs by identifying the uncertainty associated with existing wetland products.

\section{Introduction}

For their ability to emit the greenhouse gas methane $\left(\mathrm{CH}_{4}\right)$, wetland ecosystems play a disproportionately important role in affecting the global climate system through biogeochemical feedbacks (Fisher et al., 2011; Seneviratne et al., 2010). Wetlands are thought to be the largest natural source of $\mathrm{CH}_{4}$ emission by contributing $20-40 \%$ of the total annual emissions to atmosphere, which adds a strong radiative forcing from $\mathrm{CH}_{4}$ (Bousquet et al., 2006; IPCC, 2013). The seasonal 
and interannual distribution of wetland area remains one of the largest uncertainties in the global $\mathrm{CH}_{4}$ budget (Kirschke et al., 2013), in particular for the roughly $60 \%$ of wetlands that are not inundated permanently (Petrescu et al., 2010). Changes in the spatial extent of seasonally inundated wetlands was most likely a major driver for $\mathrm{CH}_{4}$ variations during last glacial period (Kaplan, 2002) and are considered as an important driver of the strong atmospheric $\mathrm{CH}_{4}$ growth rate resumed in 2007 (Nisbet et al., 2014) and in future climate change scenarios (Stocker et al., 2013).

Improving our understanding of the role of wetlands in global greenhouse gas budgets requires a representation of wetlands and their biogeochemical processes in land-surface models (LSMs) to both hindcast observed past variations (Singarayer et al., 2011) and predict future trajectories in atmospheric $\mathrm{CH}_{4}$ and terrestrial $\mathrm{C}$ balance (Ito and Inatomi, 2012; Meng et al., 2012; Spahni et al., 2011; Stocker et al., 2014; Zürcher et al., 2013). Dynamic wetland schemes in LSMs were based on conceptual theories and physical processes describing surface water processes (e.g., infiltration and evapotranspiration) and water movement in the soil column using probability distributions derived from subgrid topographic information (Beven and Kirkby, 1979) or using analytical functional parametric forms with fixed parameters (Liang et al., 1994). Currently, the most common approach for global wetland modeling is to use a runoff simulation scheme such as TOPMODEL (TOPography-based hydrological MODEL) (Beven and Kirkby, 1979; Kleinen et al., 2012; Ducharne et al., 1999; Ringeval et al., 2012; Zhu et al., 2014), which includes the assumption that lateral soil water transport driven by topography follows the same exponential decline as the vertical decrease in hydraulic conductivity within soil profiles in a basin (Sivapalan et al., 1987).

TOPMODEL-based implementations have proven successful at capturing the broad geographic distribution of wetlands and their seasonal variability (Gedney and Cox, 2003; Ringeval et al., 2012; Stocker et al., 2014; Zhu et al., 2014) but have consistently overestimated both the extent of wetlands and duration of inundation at global and regional scale when compared to existing surveys (Junk et al., 2011; Prigent et al., 2007; Quiquet et al., 2015). For instance, simulations using the Earth system model HadGEM2 predict much larger persistent Amazonian wetlands than an inventory (Collins et al., 2011). In general, independently determined wetland area using hydrologic modules of LSMs in the Wetland and Wetland $\mathrm{CH}_{4}$ Inter-comparison of Models Projects (WETCHIMP) experiment simulated larger global wetland extent than those informed by remotely sensed product and inventories (Melton et al., 2013). This large disagreement also exists across specific regions (Ringeval et al., 2014). For example, Bohn et al. (2015) carried out a model intercomparison of wetland extent on the West Siberian Lowland, one of the major wetland regions in high latitudes, and highlighted similar uncertainties of wetland extent simula- tion in the LSMs participating in the WETCHIMP experiment and using TOPMODEL.

Meanwhile, uncertainties in wetland area estimation partly come from a paucity of observational data sets and different definitions of wetland (Matthews and Fung, 1987). Remotely sensed data sets have difficulties capturing small or isolated water in saturated soils that are not flooded on the surface (Prigent et al., 2007), as well as capturing the forested wetlands that obscure detection of inundation because of dense forest canopies (Bohn et al., 2015). In addition, ground-based surveys or inventories that determine wetlands are usually limited by static distribution that cannot provide temporal patterns for the inundated area, making it hard to evaluate with simulated results. However, the definition of wetland for regional- or global-scale modeling assumes the land surface has both inundated and saturated conditions, which is not necessarily the same as inundated area measured by satellite observations (Melton et al., 2013).

While prognostic wetland dynamics schemes are promising to resolve these observational issues, the configuration parameters for TOPMODEL are a potential source of uncertainty in estimating wetland dynamics (Marthews et al., 2015). Among all parameters in TOPMODEL, the compound topographic index (CTI) is of critical importance for determining inundated areas in terrain-related hydrological applications (Ward and Robinson, 2000; Wilson and Gallant, 2000). It measures the tendency of soils to become saturated (Beven and Cloke, 2012) and consequently it drives the accuracy of wetland area scaled to the larger grid cell (Ducharne, 2009; Mulligan and Wainwright, 2013). Although the importance of CTI has been highlighted, only few studies have so far evaluated the effect of CTI on modeling the spatial and temporal patterns of global wetland dynamics. This is due to a limited availability of global CTI products. During the last decade, the first CTI product at $1 \mathrm{~km}$ resolution from HYDRO1k global data set released by US Geological Survey (USGS) in 2000 has become the most commonly applied global data set for large-scale applications (Kleinen et al., 2012; Lei et al., 2014; Ringeval et al., 2012; Wania et al., 2013). However, HYDRO1k has been proven to potentially overestimate inundation extent due to a lack in quality of the underlying digital elevation model (DEM) (Grabs et al., 2009; Lin et al., 2010, 2013; Sørensen and Seibert, 2007). With recent advances in the development of DEMs (Danielson and Gesch, 2011; Lehner et al., 2008), there is both a requirement and an opportunity to investigate uncertainties caused by CTI parameter.

The primary goal of our study is to improve the modeling of dynamically varying wetland extents with (i) a parameter constraint to match integrated satellite and inventory observations and with (ii) a better parameterizations of CTI values for determining wetland seasonal cycles using new topographic data and aggregation schemes (i.e., grid vs. catchment). To this end, we develop a new version of the Dynamic Global Vegetation Model (DGVM) LPJ-wsl (Lund- 
Potsdam-Jena Wald Schnee und Landschaft version) that includes the TOPMODEL approach for wetland extent modeling by also accounting for soil thermal dynamics and highlatitude soil water freeze and thaw (FT) cycles and by incorporating the necessary physical processes (e.g., snow aging) that constrain global wetland dynamics. We utilize three commonly used global DEM products to evaluate the effects of sub-grid parameterizations on simulated global wetland extent uncertainties. We perform six global simulations resulting from the combination of three DEM products and two aggregation schemes under the same common experimental protocol. The specific aims are (1) to improve the performance of estimated wetland extent based on TOPMODEL for the purpose of large-scale modeling, (2) to develop a new parameterization scheme using inventory in combination with satellite-based retrievals, and (3) to evaluate the uncertainties and the spatial and temporal differences of the CTI from three major DEM products in model behavior.

\section{Model descriptions and experimental design}

The model LPJ-wsl is a process-based dynamic global vegetation model developed for carbon cycle applications based on development of the LPJ-DGVM (Sitch et al., 2003). LPJwsl includes land-surface processes, such as water, carbon fluxes, and vegetation dynamics, that are intimately represented by plant functional types (PFTs) (Poulter et al., 2011). The distribution of PFTs is simulated based on a set of bioclimatic limits and by plant-specific parameters that govern the competition for resources. The soil hydrology is modeled using semi-empirical approach, with the soil treated as bucket consisting of two layers each with fixed thickness (Gerten et al., 2004). The LPJ-wsl $\mathrm{CH}_{4}$ model used in this study is the same as presented in Hodson et al. (2011) and is a function of two scaling factors $\left(\mathrm{CH}_{4}\right.$ :C and $\left.f_{\text {ecosys }}\right)$, soil temperature, soil-moisture-dependent fraction of heterotrophic respiration, and wetland extent according to the following equation:

$E(x, t)=r_{\mathrm{CH}_{4}: \mathrm{C}} \cdot f_{\text {ecosys }}(x) \cdot A(x, t) \cdot R_{\mathrm{h}}(x, t)$,

where $E(x, t)$ is wetland $\mathrm{CH}_{4}$ flux, $A(x, t)$ is wetland extent, $R_{\mathrm{h}}(x, t)$ is heterotrophic respiration, $f_{\text {ecosys }}$ is a scaling factor representing different wetland ecosystems, and $r_{\mathrm{CH}_{4}}: \mathrm{C}$ is the ratio $\mathrm{C}$ to $\mathrm{CH}_{4}$ fluxes.

LPJ-wsl has been evaluated in previous studies using global inventory data sets and satellite observations and has been one of the participating models in the WETCHIMP study (Melton et al., 2013). Modifications made here to the original LPJ-wsl model and a detailed description of changes are summarized below.

- A permafrost module that simulates soil freeze and thaw processes is implemented and modified following the Wania et al. (2009) study (see description in Sect. 2.1).
- The snow module from Wania et al. (2009) was included and modified to include some of the effects of snow ageing on snow thermal properties. We use an updated parameterization of soil thermal properties both for the permafrost and the snow module, which is calibrated by satellite observations specifically for global application.

- A new parameterization of soil texture was formulated based on the Harmonized World Soil Database (HWSD), which combines the recently collected extensive volumes of regional and national updates of soil parameter information (Nachtergaele et al., 2008). The new soil texture in LPJ-wsl follows the US Department of Agriculture soil classification with 14 soil types grouped according to a particular range of particle-size fractions (e.g., sand, clay, loam), instead of using the original Food and Agriculture Organization of the UN classification with nine soil types (Sitch et al., 2003). Thus, the volumetric water holding capacity, also defined as potential maximum soil water content, is assumed to vary spatially, calculated as a function of the surface soil texture using pedotransfer functions from Cosby et al. (1984). Wilting point, porosity, mineral soil content, and organic soil content for each soil type are derived from a look-up table available from the Air Force Weather Agency (2002) as listed in Table 1.

The modified LPJ-wsl version is thus the starting point upon which the TOPMODEL-based wetland and permafrost modules are included (Sect. 2.2).

\subsection{Permafrost model}

In order to consider the functional wetland area extension during the spring thaw and their shrinking or disappearances during autumn freeze, we added to LPJ-wsl a soil temperature scheme and freeze-thaw processes, as in Wania et al. (2009). The modified version considers the soil heat capacity and its thermal conductivity, which are both affected by the volumetric fractions of the soil physical components, such as water-ice fraction, mineral soil, or peat. The thermal scheme of LPJ-wsl is discretized vertically using eight layers of variable thickness, while the water-balance scheme is kept the same as the original LPJ-DGVM, which means the daily changes in water content are allocated to the "old" upper and lower layer of LPJ while considering percolation between these two layers and baseflow from the lower layer. Fractional water and ice content in each of the eight layers is calculated on a daily time step. Soil temperature is updated in the thermal routine and then passed to the hydrological routine to determine the water-ice phase change in permafrost routine. 
Table 1. Soil parameters for LPJ-wsl soil classes. $\mathrm{f}$ is a parameter describing the exponential decline of transmissivity with depth for each soil type.

\begin{tabular}{llllll}
\hline Soil type & $f$ & $\begin{array}{l}\text { Mineral } \\
\text { content }(\%)\end{array}$ & $\begin{array}{l}\text { Organic } \\
\text { content }(\%)\end{array}$ & $\begin{array}{l}\text { Wilting } \\
\text { point }(\%)\end{array}$ & $\begin{array}{l}\text { Porosity } \\
(\%)\end{array}$ \\
\hline Clay heavy & 3.2 & 0.508 & 0.01 & 0.138 & 0.138 \\
Silty clay & 3.1 & 0.531 & 0.01 & 0.126 & 0.468 \\
Clay & 2.8 & 0.531 & 0.01 & 0.138 & 0.468 \\
Silty clay loam & 2.9 & 0.534 & 0.01 & 0.120 & 0.464 \\
Clay loam & 2.7 & 0.595 & 0.01 & 0.103 & 0.465 \\
Silt & 3.4 & 0.593 & 0.01 & 0.084 & 0.476 \\
Silt loam & 2.6 & 0.593 & 0.01 & 0.084 & 0.476 \\
Sandy clay & 2.5 & 0.535 & 0.01 & 0.100 & 0.406 \\
Loam & 2.5 & 0.535 & 0.01 & 0.066 & 0.439 \\
Sandy clay loam & 2.4 & 0.565 & 0.01 & 0.067 & 0.404 \\
Sandy loam & 2.3 & 0.565 & 0.01 & 0.047 & 0.434 \\
Loamy sand & 2.2 & 0.578 & 0.01 & 0.028 & 0.421 \\
Sand & 2.1 & 0.578 & 0.01 & 0.010 & 0.339 \\
Organic & 2.5 & 0.01 & 0.20 & 0.066 & 0.439 \\
\hline
\end{tabular}

\subsection{Dynamic wetland model}

To represent the grid cell fraction covered by wetlands, we have implemented an approach based on the TOPMODEL hydrological framework (Beven and Kirkby, 1979). TOPMODEL was initially developed to operate at the scale of large watersheds using the channel network topography and dynamics contributing areas for runoff generation and was later extended to perform over areas that are much larger than a typical river catchment (Gedney and Cox, 2003). The fundamental information to determine the area fraction with soil water saturation is derived from knowledge of the mean watershed water table depth and a probability density function of combined topographic and soil properties (Sivapalan et al., 1987). The CTI, which provides the sub-grid-scale topographic information in TOPMODEL, determines the likelihood of a grid box to be inundated. It is defined as

$\lambda_{1}=\ln \left(\frac{\alpha_{1}}{\tan \beta_{1}}\right)$,

where $\lambda_{1}$ represents local CTI value, $\alpha_{1}$ represents the contributing area per unit contour, and $\tan \beta_{1}$, the local topographic slope, approximates the local hydraulic gradient where $\beta$ is the local surface slope. The CTI distribution can be generated from digital elevation models and near global data sets are readily available, e.g., HYDRO1k data set from USGS.

Following the central equations of TOPMODEL, the relationship between local water table depth $z_{1}$ and the grid mean water table depth $z_{\mathrm{m}}$ can be given as

$\lambda_{1}-\lambda_{\mathrm{m}}=f\left\{z_{1}-z_{\mathrm{m}}\right\}$,

where $\lambda_{\mathrm{m}}$ is the mean CTI averaged over the grid box, and $f$ is the saturated hydraulic conductivity decay factor with depth for each soil type. This equation is valuable in that it relates the local moisture status to the grid box mean moisture status based on the subgrid-scale variations in topography. Higher CTI values than average are indicative of areas with higher water table depth than average water table and vice versa. We therefore calculate the inundated areas $\left(F_{\text {wet }}\right)$ of all the sub-grid points within a grid cell that have a local water table depth $z_{1}>=0$ :

$F_{\text {wet }}=\int_{z_{1}}^{z_{\max }} \operatorname{pdf}(\lambda) d_{\lambda}$,

where instead of using the CTI values themselves, we followed a common up-scaling approach to approximate the distribution of CTI values within a grid cell in order to reduce computation costs. Here, the discrete distribution of the CTI for lowland pixels (i.e., $\lambda_{1} \geq \lambda_{\mathrm{m}}$ ) has been represented as an exponential function, not as a three-parameter gamma distribution as applied in recent applications for modeling wetland extent (Kleinen et al., 2012; Ringeval et al., 2012). As shown in Fig. 1, the new exponential function agrees well with the three-parameter gamma distribution function when the CTI is larger than the mean CTI $\lambda_{\mathrm{m}}$. This change allows linking the inundated fraction directly to water table depth, thus improving the parameterization by providing physical meaning and fewer calibration parameters. This change also improves the parameterization of fractional saturated area, especially in mountainous regions (Niu et al., 2005).

Finally, the wetland area fraction $\left(F_{\text {wet }}\right)$ is represented as

$F_{\text {wet }}=F_{\max } e^{-C_{\mathrm{s}} f\left(\lambda_{1}-\lambda_{\mathrm{m}}\right)}$,

where $C_{\mathrm{s}}$ is a coefficient representing the topographic information generated by fitting the exponential function to the discrete cumulative distribution function (CDF) of the CTI. 


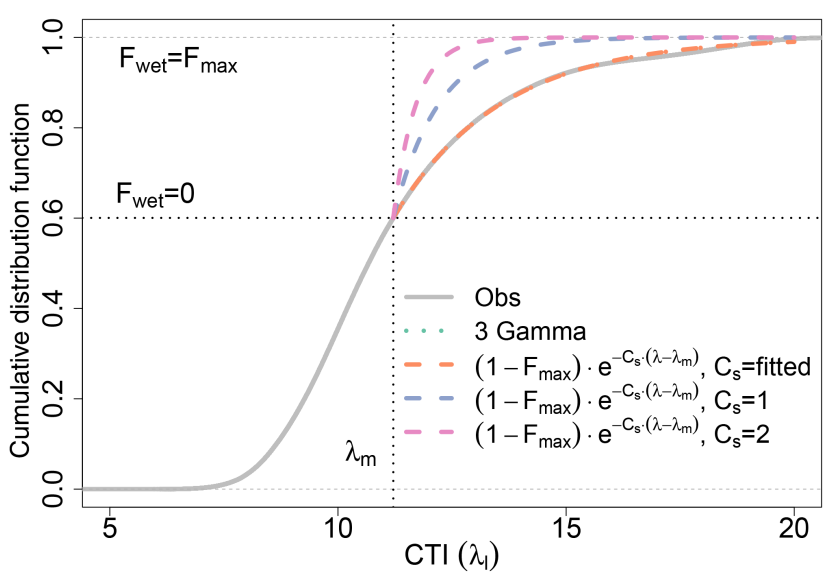

Figure 1. Cumulative distribution function (CDF) of the fitted exponential curve (blue line) as a function of compound topographic index (CTI) in comparison with the three-parameter gamma function (red line), as well as the observations (grey line) with in a sample grid box.

$F_{\max }$ is the maximum wetland fraction of a grid cell. Because of the uncertainties involved in determining the water table depth, the hydraulic factor $f$, and the coarse-resolution DEMs, the maximum soil saturated fraction calculated from discrete CDF are prone to large uncertainties and thus complicate the comparison of the saturated fraction with existing observations (Ducharne, 2009; Ringeval et al., 2012). Here, we introduce a calibration of maximum wetland fractions $F_{\max }$. We used the inventory-calibrated satellite observations (see description in Sect. 3.3) combined with inventory data set to calculate representative long-term maximum wetland extents within each grid box $\left(0.5^{\circ}\right)$, i.e., the parameter $F_{\max }$ for each grid cell $i$ :

$F_{\max _{i}}=\max \left(A_{\mathrm{GLWD}_{\mathrm{i}}}, \max \left(A_{\mathrm{SWAMP}-\mathrm{GLWD}_{\mathrm{i}}}\right)\right)$.

$A_{\text {GLWD }}$ represents the wetland estimate from the Global Lake and Wetland Database (GLWD), and $A_{\text {SWAMP-GLWD }}$ represents the long-term wetland estimate from a combination of the satellite-based observation Surface Water Microwave Product Series (SWAMPS) and GLWD (SWAMPS-GLWD). The reason for combining these two data sets is to take advantage of satellite-based observations that capture temporal wetlands and inventory-based data sets that estimate forested wetlands and small wetlands ignored by remote sensing. This calibration is also based on the assumption that water is stagnant within local grids at a large scale, in particular for model using simple "bucket" concept to calculate grid-mean water table depth.

In addition, we used nonlinear least squares estimates to fit the discrete CDF curve of CTI for lowlands $\left(\lambda_{1}<\lambda_{\mathrm{m}}\right)$ to calculate parameter $C_{\mathrm{s}}$, the parameter that determines varying trend of wetland extent. Through this, the parameters $F_{\max }, \lambda_{\mathrm{m}}$ and $C_{\mathrm{s}}$ for determining inundated areas are derived (Fig. 2).
To account for the permafrost effects on soil infiltration properties, we followed Fan and Miguez-Macho (2011) and Kleinen et al. (2012) who modified $f$ by a function $k$ depending on January temperature $T_{\text {jan }}$. Since LPJ-wsl uses two soil layers from the HWSD soil texture database (Nachtergaele et al., 2008) to represent the different texture characteristics, the modification depends on the combination of a look-up table (Table 1) from soil types and water table depth:

$k= \begin{cases}1 & \forall T_{\text {jan }}>-5^{\circ} \\ 1.075+0.015 T_{\text {jan }} & -25^{\circ}<\forall T_{\text {jan }}<-5^{\circ} . \\ 0.75 & \forall T_{\text {jan }}<-5^{\circ}\end{cases}$

Since the observed $\mathrm{CH}_{4}$ emissions during winter are mainly attributed to physical processes during soil freezing effects (Whalen and Reeburgh, 1992), for the partially frozen wetland in high latitudes, we introduced an effective fraction of wetland area $\left(F_{\text {wet }}^{\text {eff }}\right)$ defined by

$F_{\mathrm{wet}}^{\mathrm{eff}}=\left(\frac{\omega_{\mathrm{liq}}}{\omega_{\mathrm{liq}}+\omega_{\mathrm{froz}}}\right)_{50 \mathrm{~cm}} \cdot F_{\mathrm{wet}}$,

where $\omega_{\mathrm{liq}}$ and $\omega_{\mathrm{froz}}$ are the fraction of liquid and frozen soil water content in the upper soil $(0-0.5 \mathrm{~m})$, respectively. Since the liquid water content in the lower soil layer gets trapped and cannot contribute to $\mathrm{CH}_{4}$ emission when upper soil is frozen, we did not consider the lower layer for surface wetland calculations.

\section{Experimental setup and data sets}

\subsection{Topographic information}

In this study we used three DEMs of varying spatial resolution, HYDRO1k at 30 arcsec (USGS, 1996; https://lta.cr. usgs.gov/HYDRO1K), Global Multi-resolution Terrain Elevation Data 2010 (GMTED) at $15 \operatorname{arcsec}$ (Danielson and Gesch, 2011), and HydroSHEDS at 15 arcsec (Lehner et al., 2008) to compare the effect of sub-grid topographic attributes on simulated seasonal and interannual variability of wetlands. HYDRO1k, developed from the USGS-released 30 arcsec digital elevation model of the world (GTOPO30), is the first product that allowed spatially explicit hydrological routines applied in large-scale applications (USGS, 2000). HydroSHEDS, developed from satellite-based global mapping by the Shuttle Radar Topography Mission (SRTM), is a significant improvement in the availability of high-resolution DEMs covering all land areas south of $60^{\circ} \mathrm{N}$ (the limit of SRTM). For the areas at higher latitudes we used HYDRO1k by aggregating the GTOPO30 DEM to provide global grids. GMTED was produced using seven data sources including SRTM, global Digital Terrain Elevation Data (DTED), Canadian elevation data, Spot 5 Reference3D data, and data from the Ice, Cloud, and land Elevation Satellite (ICESat), covering nearly all global terrain. 


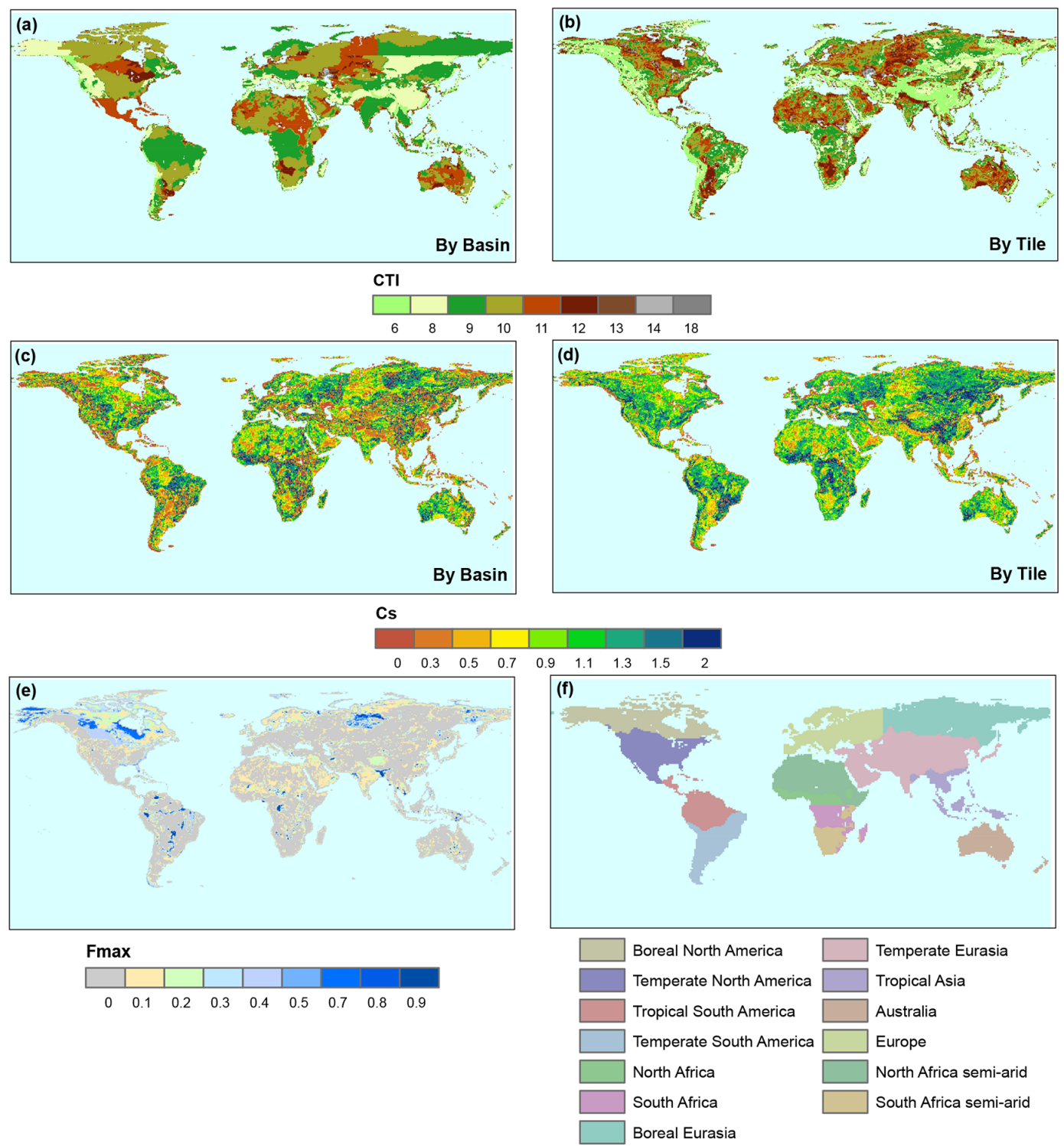

Figure 2. TOPMODEL parameter maps in model experiments. Mean CTI (a, b) and $C_{\mathrm{s}}(\mathbf{c}, \mathbf{d})$ aggregated by river-basin (denoted as "By Basin") and grid-cell (denoted as "By Tile") schemes from HydroSHEDS were listed. $F_{\max }(\mathbf{e})$ for calibration was generated using SWAMPSGLWD and GLWD. A map of the regions (f) was used to partition globe into boreal, temperate, and tropical biomes (Gurney et al., 2003).

To avoid mismatch of CTI value inherent in computing CTI with different CTI algorithms, we generated three global CTI maps based on the three DEM products instead of relying on existing CTI products (e.g., HYDRO1k CTI, HydroSHEDS CTI product from the Centre for Ecology and Hydrology) (Marthews et al., 2015). Since studies show that multiple flow direction algorithms for calculating CTI give better accuracy compared to single-flow algorithms in flat areas (Kopecký and Č́žková, 2010; Pan et al., 2004), thus we selected an algorithm from R library "topmodel" (Buytaert, 2011), which applies the multiple flow routing algorithm of Quinn et al. (1995) to calculate the global CTI maps. The DEMs from HYDRO1k and HydroSHEDS had been pre- viously processed for hydrological correction, meaning that the DEMs were processed to remove elevation depressions that would cause local hydrologic "sinks". To include a comparison of (hydrologically) corrected and uncorrected DEMs in our analyses as some studies have been done previously (Stocker et al., 2014), the GMTED DEM was applied without hydrological correction.

\subsection{Description of the simulation}

For running LPJ-wsl with permafrost and TOPMODEL, we used global meteorological forcing (temperature, cloud cover, precipitation, and wet days) as provided by the Climatic Research Unit (CRU TS 3.22) at $0.5^{\circ}$ resolution (Har- 
ris et al., 2014). To spin up the LPJ-wsl model using the CRU climatology, climate data for 12 months were randomly selected from 1901 to 1930 and repeated for 1000 years with a fixed pre-industrial atmospheric $\mathrm{CO}_{2}$ concentration. The first spinup simulation started from initial soil temperature derived from LPJ-wsl simulated results on January 1901 and continued with a land-use spinup simulation. These procedures ensure that carbon stocks and permafrost are in equilibrium before performing transient simulations. The transient simulations, with observed climate and $\mathrm{CO}_{2}$, were performed with monthly climate disaggregated to daily time steps over the 1901-2013 period. The 1993-2013 years were used for evaluation against satellite data and inventories.

One of key assumptions in TOPMODEL is that the water table is recharged at a spatially uniform and steady rate with respect to the flow response timescale of the catchment (Stieglitz et al., 1997). Given the fact that we consider the water to be stagnant within each grid, the mean CTI parameter was estimated with two alternative schemes: (1) a regular "grid-based" or gridded approach, i.e., the subgrid CTI values were averaged per $0.5^{\circ}$ grids, and (2) an irregular "basinbased" approach, where mean CTI values were calculated over the entire catchment area in which the respective pixel is located. To generate a global catchment map at $0.5^{\circ}$ resolution, we applied a majority algorithm in the case of multicatchments in a grid while avoiding isolated pixels for the specific river basin. There are two catchment area products applied in this study, HYDRO1k (2013) and HydroSHEDS. Similarly, the parameter $C_{\mathrm{s}}$ was generated using nonlinear least squares estimates from both of these two different CTI calculation strategies. Two sets of model experiments were carried out to compare the wetland dynamics under basin and grid-based TOPMODEL parameterizations (Table 2).

\subsection{Evaluation and benchmarking data}

Since the soil freeze-thaw cycles are a key component for determining seasonal cycles of wetlands in cold regions, in this study we benchmarked the general pattern of permafrost locations by comparing the model output against satellite observations of freeze and thaw status and inventories of permafrost extent. Since soil depth in LPJ-wsl is held at $2.0 \mathrm{~m}$ for the permafrost module, the permafrost extent in this study is defined as the lower soil $(0.5-2 \mathrm{~m})$ that is always at or below the freezing point of water $\left(0^{\circ} \mathrm{C}\right)$ for multiple years. The permafrost extent map at $0.5^{\circ}$ resolution from the National Snow and Ice Data Center (NSIDC) is adopted for benchmarking (Brown et al., 2001). The global data set of freezethaw Earth System Data Record (FT-ESDR) is derived from satellite microwave remote sensing provided by the Numerical Terradynamic Simulation Group (NTSG) at the University of Montana and is based on daily maps over a 34-year record (1979-2012). It represents the FT status of the composite landscape vegetation-snow-soil medium to constrain surface water mobility and land-atmosphere carbon fluxes (Kim et al., 2012).

Two global inundation products derived from satellite observations were additionally used for evaluation purposes: the Global Inundation Extent from Multi-Satellites (GIEMS), derived from visible (AVHRR), active (SSM/I), and passive (ERS) microwave sensors over the period 1993-2007; SWAMPS, derived from active (SeaWinds-onQuikSCAT, ERS, and ASCAT) and passive (SSM/I, SSMI/S, AMSR-E) microwave sensors over the period 1992-2013. This new SWAMPS global data set, denoted as SWAMPSGLWD, was first developed at NASA JPL (Schroeder et al., 2016). We re-scaled this data set with the GLWD (Lehner and Döll, 2004), a well-established global inventory of water bodies at high resolution to match SWAMPS-GLWD with the inventory estimates. This post-processed SWAMPS product covers the required regions for forested wetlands, which are not readily observable by passive or active microwave measurements (Poulter, et al., 2015). For evaluating regional wetland patterns, we selected two study areas (the largest peatland, West Siberian Lowland; the largest floodplain, Amazon River basin). Three wetland map products over the WSL from Sheng et al. (2004), Peregon et al. (2008), and Tarnocai et al. (2009) (denoted by "Sheng2004", "Peregon2008", Tarnocai2009, respectively) and one up-to-date high-resolution dual-season inundated area inventory for the lowland Amazon basin from Japanese Earth Resources Satellite (JERS-1) were applied (Hess et al., 2015, denoted by "Hess2015"). We aggregated all above-mentioned data sets from the native $25 \mathrm{~km}$ to a $0.5^{\circ}$ spatial resolution and from daily to monthly temporal resolution for comparison with model outputs (Appendix Table A1).

\section{Results}

\subsection{Evaluation against observations}

We first evaluated the permafrost module that constrains the seasonal cycles of wetland area in cold regions with respect to inventory and remote sensing observations. Figure $3 \mathrm{a}$ compares the spatial distribution of permafrost extent from inventory and the modeled permafrost extent over the period 1980-2000. Figure 3b gives the spatial distribution of spearman rank correlation between the simulated and observed number of monthly frozen days. The modeled permafrost extent shows high agreement with the benchmarking data set, with a slightly higher coverage of permafrost regions in northwestern Eurasia. The model successfully captures the seasonally frozen soil, which is closely linked to surface wetland formation and seasonal variation of wetland in cold regions. Most of the regions reveal a temporal correlation $>0.9$, while eastern Siberia and the southern permafrost distribution edge is generally around 0.5 . The lower correlation in eastern Siberia probably originates from two issues: 
Table 2. Model experiments for different parameterization schemes and corresponding DEM products applied in this study.

\begin{tabular}{llllllll}
\hline $\begin{array}{l}\text { Model } \\
\text { experiment }\end{array}$ & DEM & DEM source & $\begin{array}{l}\text { Resolution } \\
\text { (arc seconds) }\end{array}$ & Coverage & River basin & Aggregation type & Hydro-corrected \\
\hline HYDRO1k_BASIN & Hydro1k & GTOPO30 & 30 & Global* & HYDRO1K & Catchment & Yes \\
HYDRO1k_GRID & Hydro1k & GTOPO30 & 30 & Global* $^{*}$ & HYDRO1K & Grid & Yes \\
GMTED_BASIN & GMTED & SRTM\&others & 15 & Global & HYDRO1K & Catchment & No \\
GMTED_GRID & GMTED & SRTM\&others & 15 & Global & HYDRO1K & Grid & No \\
SHEDS_BASIN & HydroSHEDS & SRTM & 15 & $<60^{\circ} \mathrm{N}$ & HydroSHEDS & Catchment & Yes \\
SHEDS_GRID & HydroSHEDS & SRTM & 15 & $<60^{\circ} \mathrm{N}$ & HydroSHEDS & Grid & Yes \\
\hline
\end{tabular}
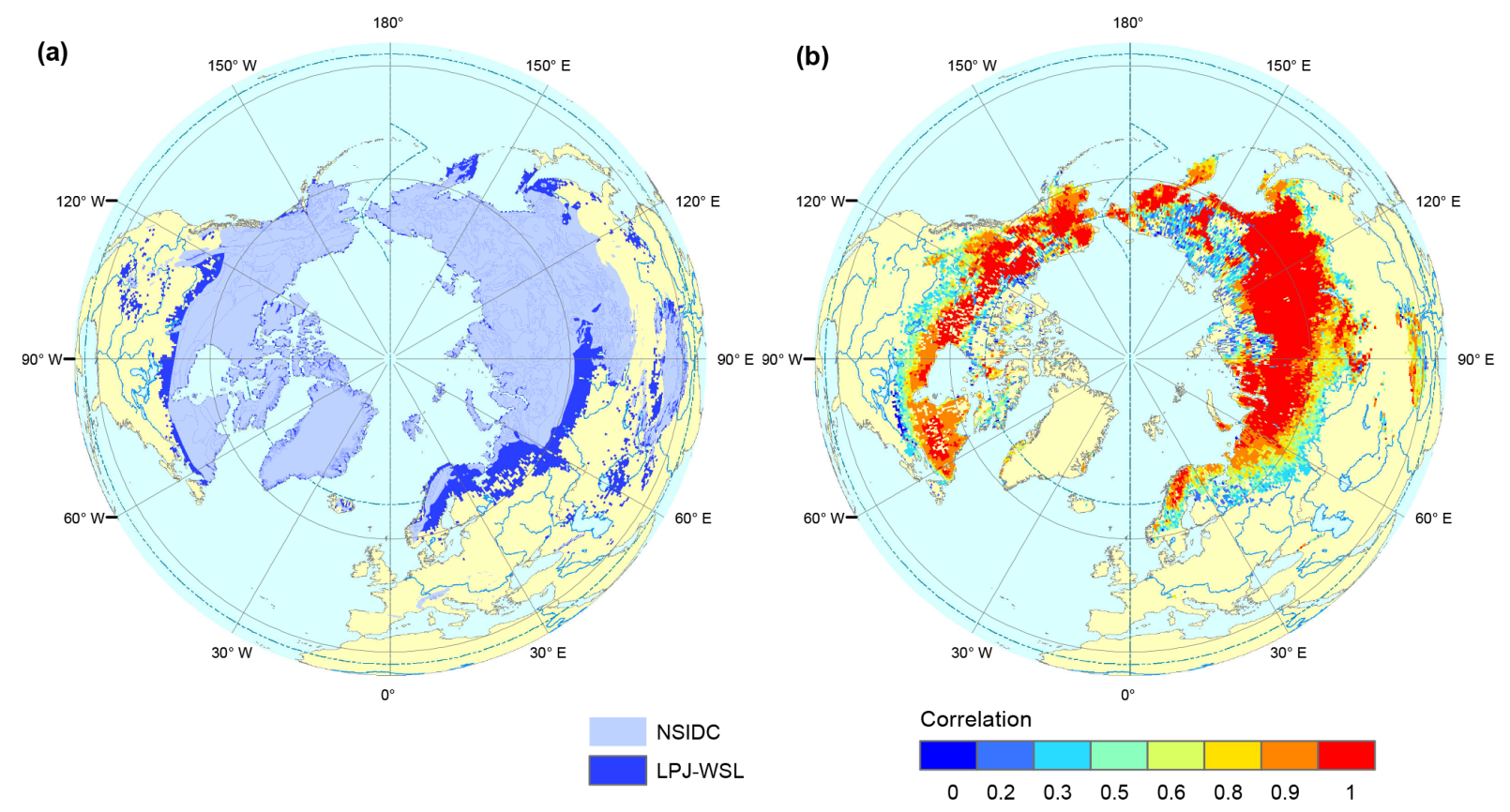

Figure 3. Evaluation of permafrost simulation in LPJ-wsl. (a) Inventory-based (light blue) and simulated (dark blue) permafrost extent from NSIDC and LPJ-wsl, respectively. The inventory contains discontinuous, sporadic, or isolated permafrost boundaries, as well as the location of sub-sea and relict permafrost. We only compare the distribution of all permafrost against model outputs without distinguishing each permafrost types. (b) Spatial distribution of Spearman correlation between simulated monthly frozen days from LPJ-wsl over 2002-2011 and satellite retrievals of freeze-thaw status from AMSR-E.

high snow depth in LPJ-wsl that insulates soil temperature and the consequent delay of soil temperature to reach complete freezing as well as the relatively large uncertainty of FT-ESDR-derived soil frozen status in those regions (Kim et al., 2012). This difference can be partly explained by the different representation of frozen status between simulated results and satellite retrievals. Remotely sensed maps reflect the mixed condition of the upper vegetation canopy, snow layer, and surface soil, while the simulated frozen days only represent the frozen state of topsoil.

Figure 4 illustrates the model evaluation at the regional scale over the West Siberian Lowland (Fig. 4). The model generally captures the spatial extent of the seasonal maximum wetland area fraction across the whole WSL for the JJA season successfully. However, the TOPMODEL approach without calibration (denoted as "Original") shows large areas with relatively low wetland proportion and cannot capture high values. This suggests poor model performance in simulating wetland areas without $F_{\max }$ calibration. The calibrated model generally exhibits good agreement with inventories and satellite retrievals. It is especially successful at capturing the spatial heterogeneity of wetland areal extent over the whole WSL regions. LPJ-wsl simulated results reveal additional wetland area in the northeast, where wetlands entirely lacked in the GLWD map, although they were captured in other data sets. Meanwhile, LPJ-wsl captured the higher wetland area in region between 61 and $66^{\circ} \mathrm{N}$ and 70 and $80^{\circ} \mathrm{E}$ regions compared with GLWD, where mire/bog/fen was dominated across that region. LPJ-wsl also maintained well the spatial pattern of wetlands in forested region south of $60^{\circ} \mathrm{N}$, which was captured by inventories (Sheng2004, Peregon2008, and GLWD) but was missed by two satellite 


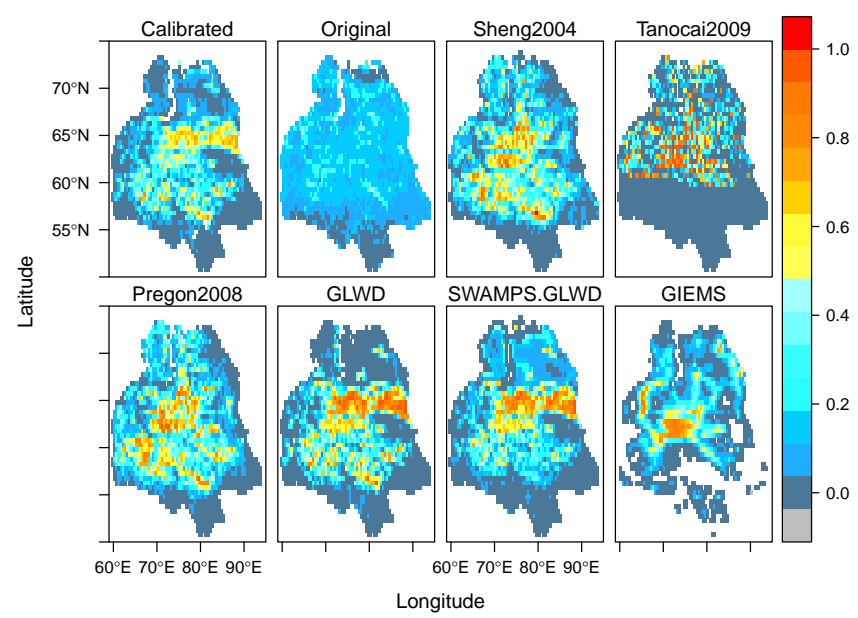

Figure 4. Comparison of TOPMODEL-based wetland areas and Observational data sets over the region West Siberian Lowland (WSL) for June-July-August (JJA) average over the period 19932012. "Calibrated" and "Original" represent simulated wetland areas with and without $F_{\max }$ calibration, respectively. For Sheng2004, Tanocai, Pregon2008, and GLWD, it represents maximum wetland extent per $0.5^{\circ}$ cell as derived from static inventory maps. For SWAMPS-GLWD and GIEMS, areas shown are averaged for JJA over the period 1993-2007 and 2000-2012, respectively.

products (SWAMPS-GLWD, GIEMS) due to the limitation of remotely sensed data sets in detecting water under vegetative canopy and/or due to reduced sensitivity.

As illustrated in Fig. 5, LPJ-wsl captured the spatial pattern of simulated wetlands well with lower estimates of the total wetland area in low-water season compared to the JERS-1 observed maps. Differences between Hess2015 and LPJ-wsl maps were primarily in two regions, MarañónUcayali region of Peru (MUP; $3-7^{\circ} \mathrm{S}, 73-77^{\circ} \mathrm{W}$ ) and Llanos de Moxos in Bolivia (LMB; $11-17^{\circ} \mathrm{S}, 60-68^{\circ} \mathrm{W}$ ). LPJ-wsl shows higher wetland coverage in MUP while Hess2015 indicates high wetland fraction in LMB in high-water season. Global satellite products largely ignore the LMB region that was partly captured in LPJ-wsl, indicating that LPJ-wsl using hybrid TOPMODEL approach can yield estimates closer to those of fine-resolution mapping, while large-scale satellite products are likely to underestimate Amazon wetland extent because of their coarse spatial resolution that limit the ability to detect inundation outside of large wetlands and river floodplains (Hess et al., 2015).

To evaluate the effect of $F_{\max }$ calibration on $\mathrm{CH}_{4}$ emission estimates, two estimates of $\mathrm{CH}_{4}$ (with and without $F_{\max }$ calibration) over the WSL regions were compared with observation-based estimate from Glagolev et al. (2011) (Fig. 6). The 3-year mean annual total emission from original version is $6.29 \pm 0.51 \mathrm{Tg} \mathrm{CH}_{4} \mathrm{yr}^{-1}$, falling into the upper part of range from land-surface models and inversions (Bohn et al., 2015), whereas the calibrated version is close to the estimate of Glagolev et al. (2011) (3.91 $\pm 1.29 \mathrm{Tg} \mathrm{CH}_{4} \mathrm{yr}^{-1}$ )

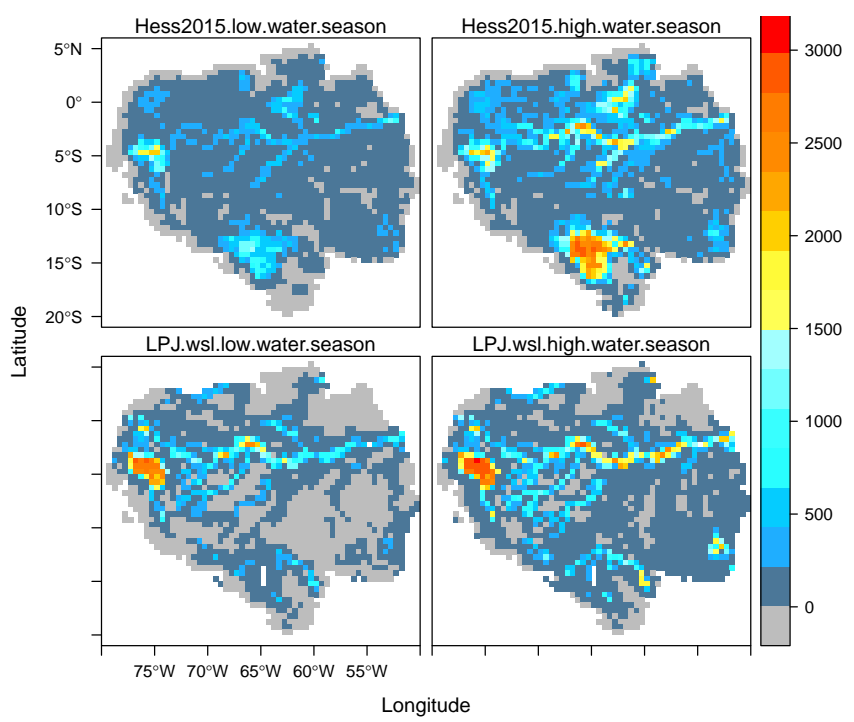

Figure 5. Comparison of wetland areas $\left(\mathrm{km}^{2}\right)$ between LPJ-wsl simulated results (SHEDS_basin version) and JERS-1 satellite observation over the lowland Amazon basin for low-water season and high-water season. The low-water season and high-water season in LPJ were calculated by mean annual minimum and maximum, respectively, during 1993-2013.

with $4.6 \pm 0.45 \mathrm{Tg} \mathrm{CH}_{4} \mathrm{yr}^{-1}$ during 2000-2012. In addition, the spatial pattern of $\mathrm{CH}_{4}$ emission with $F_{\max }$ calibration shows better agreement with observation than noncalibration one with relatively larger emissions in Taiga forests and central region $\left(55-65^{\circ} \mathrm{N}, 65-85^{\circ} \mathrm{E}\right)$. We also compared our estimates with recent airborne campaign observations for Alaska during the 2012 growing season. Estimates with $F_{\max }$ calibration also falls well within the range of recent estimate $\left(2.1 \pm 0.5 \mathrm{Tg} \mathrm{CH}_{4} \mathrm{yr}^{-1}\right)$ for Alaska based on airborne observations (Chang et al., 2014) with a total of $1.7 \mathrm{Tg} \mathrm{CH}_{4} \mathrm{yr}^{-1}$ during the 2012 growing season (3.1 $\mathrm{Tg} \mathrm{CH}_{4} \mathrm{yr}^{-1}$ from non-calibrated estimate), indicating the necessity to calibrate $F_{\max }$ to accurately capture annual $\mathrm{CH}_{4}$ emission and spatial variability for boreal wetlands.

\subsection{Spatial distribution}

Several observations applicable to evaluate the difference among sub-grid parameterizations of TOPMODEL are available for the WSL region. Figure 7 lists the spatial patterns of simulated JJA (June-July-August) wetland area over WSL regions to illustrate differences among wetland maps. The general patterns of wetland extent are substantially similar, because they both used the same calibrated $F_{\max }$ map. Both of these data sets show wetlands distributed across most of the WSL, with extensive wetlands in the central region (55$65^{\circ} \mathrm{N}, 60-90^{\circ} \mathrm{E}$ ). However, the detailed pattern is differing between the approaches and DEMs used, which indicate the uncertainty of parameterizations on wetland distribution. The basin-based parameterization can capture the higher wetland 


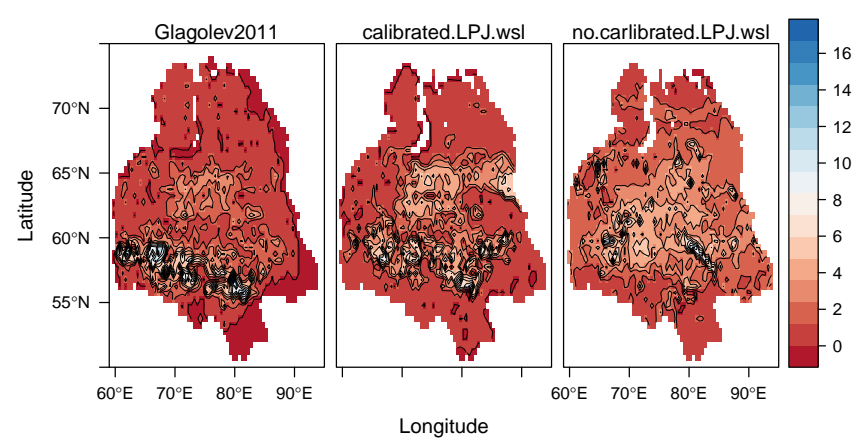

Figure 6. Observation-based estimate from Glagolev et al. (2011) and two LPJ-wsl estimates using Hydro-SHEDS (calibrated $F_{\text {max }}$ and non-calibrated $F_{\max }$ ) for annual $\mathrm{CH}_{4}$ emission $\left(\mathrm{g} \mathrm{CH}_{4} \mathrm{~m}^{-2} \mathrm{yr}^{-1}\right.$ of grid cell area). Averages from LPJ-wsl are over the time period 2007-2010.

areas in regions with bog, mire, or fen vegetation in the central east $\left(63-67^{\circ} \mathrm{N}, 85-90^{\circ} \mathrm{E}\right)$ as was found in the GLWD benchmark map. The grid-based parameterizations fail to reproduce this pattern. It seems that the grid-based parameterizations are less sensitive capturing the spatial heterogeneity throughout most of the WSL. The difference in parameterization derived from DEM data sets also affects the simulated regional pattern. Both of HydroSHEDS-based results successfully reproduce the high wetland fractions in the southern-forested regions $\left(55-60^{\circ} \mathrm{N}, 65-80^{\circ} \mathrm{E}\right)$, while neither HYDRO1k nor GMTED can capture this feature. Note that GMTED is derived from the same DEM product SRTM as HydroSHEDS but without hydro-correction, indicating the importance of hydro-correction in simulating spatial patterns of wetlands.

The comparison of simulated mean annual minimum, maximum, and amplitude of wetland extent with observational data sets (Table 3) reveals that the simulated wetland area for 1980-2010 falls within the range of $4.37 \pm 0.99 \mathrm{Mkm}^{2}\left(\mathrm{Mkm}^{2}=10^{6} \mathrm{~km}^{2}\right)$. This number is close to GIEMS (5.66 $\left.\mathrm{Mkm}^{2}\right)$ (Prigent et al., 2012) and inventorybased estimates $\left(6.2 \mathrm{Mkm}^{2}\right)$ (Bergamaschi et al., 2007) after exclusion of other water bodies like lakes, rivers, and rice paddies (Leff et al., 2004). Considering potential underestimation of satellite-based observation in forested regions, the realistic estimate could possibly be in the upper part of our range. Note that one must be careful when directly comparing model results with the observational data sets based on inventories or digitized maps, because these data sets might represent the long-term maximal area as wetland potential. The higher seasonal wetland extent in GIEMS compared with LPJ-wsl could be partly due to permanent wetlands that are difficult to detect by GIEMS. Lastly, the definition of wetland is another possible source of discrepancy. Remotely sensed inundation data sets emphasize open water while the wetland area in our study is specifically defined from inventories following the National Wetlands Working

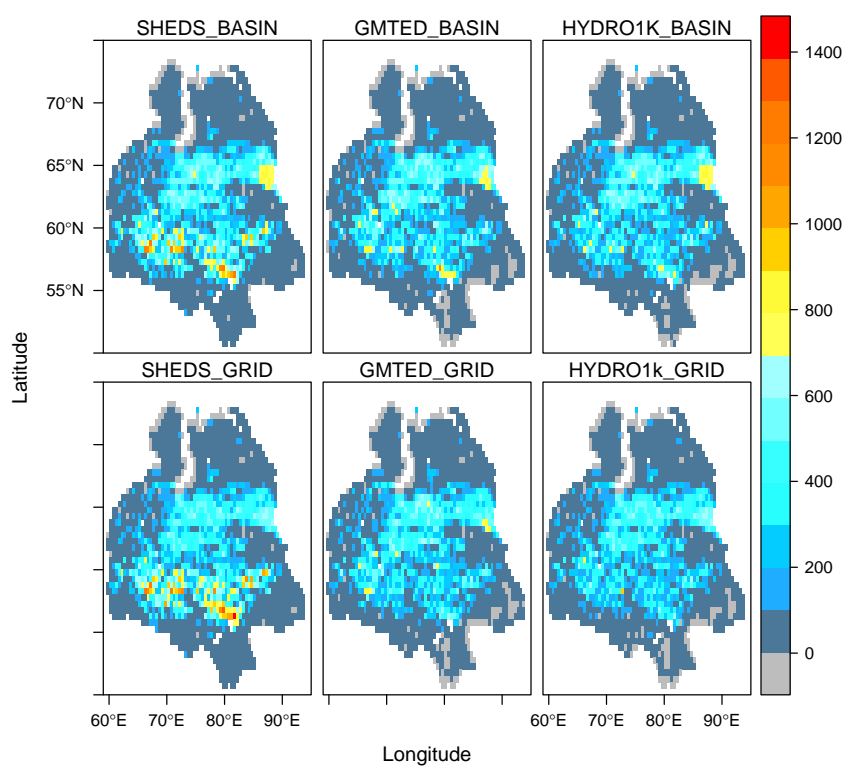

Figure 7. Spatial distributions of average June-July-August (JJA) wetland area $\left(\mathrm{km}^{2}\right)$ over the West Siberian Lowland (WSL) area from model experiments (see Table 2).

Group (1997) classification that include peatlands, mineral wetlands, and seasonally inundated shallow waters.

\subsection{Seasonal cycle}

The shapes of the seasonal patterns in wetland area are generally similar in model simulation compared to satellite observations, despite disagreement in the timing of the seasonal cycle of wetland area in some boreal regions (Fig. 8). The modeled results show slightly larger wetland areas in the SON (September-November) months than satellite-based observations. The larger seasonal wetland areas during SON may originate from the longer periods of unfrozen and relatively water saturated soil in the model data. It thus seems realistic that the satellite-based inundation product AMSRE observed a similar trend of seasonal inundation patterns for North America and Boreal Eurasia (Jennifer et al., 2014). This is also supported by field studies in boreal regions, indicating that water table depth during the SON months is still at a high level and soil temperature is above freezing status (Rinne et al., 2007; Turetsky et al., 2014). In contrast, the modeled seasonal cycle of wetland in tropical and temperate regions shows a good agreement with GIEMS and SWAMPS-GLWD. Given the difficulties of satellite-based observations in detecting wetlands in forested regions and the reduced sensitivity where open water fraction is low $(<10 \%)$ (Prigent et al., 2007), the inundation numbers by GIEMS might slightly underestimate the area compared with the simulated results.

Figure 8 reveals that the six data sets of monthly wetland extent for 1993-2007 based on different TOPMODEL pa- 
Table 3. Summary of simulated and observed mean annual minimum (MIN), maximum (MAX), and amplitude (AMP) of wetland extent for 1980-2010. All units are $\mathrm{Mkm}^{2}\left(10^{6} \mathrm{~km}^{2}\right) \pm 1 \sigma$, where standard deviation represents the interannual variation in model estimates except for the row Average, which represents uncertainties of estimates from each model experiment.

\begin{tabular}{lllllllllc}
\hline \multirow{2}{*}{ Model } & \multicolumn{3}{c}{ Lowland Amazon basin } & \multicolumn{2}{c}{ West Siberian Lowland } & \multicolumn{2}{c}{ Global } \\
\cline { 2 - 10 } & MIN & MAX & AMP & MIN & MAX & AMP & MIN & MAX & AMP \\
\hline SHEDS_BASIN & $0.27 \pm 0.02$ & $0.38 \pm 0.01$ & $0.11 \pm 0.01$ & $0 \pm 0$ & $0.45 \pm 0.05$ & $0.45 \pm 0.05$ & $2.96 \pm 0.06$ & $5.17 \pm 0.11$ & $2.23 \pm 0.10$ \\
SHEDS_GRID & $0.32 \pm 0.01$ & $0.40 \pm 0.01$ & $0.08 \pm 0.01$ & $0 \pm 0$ & $0.45 \pm 0.05$ & $0.45 \pm 0.05$ & $3.56 \pm 0.06$ & $5.93 \pm 0.11$ & $2.38 \pm 0.10$ \\
GMTED_BASIN & $0.21 \pm 0.02$ & $0.35 \pm 0.01$ & $0.14 \pm 0.02$ & $0 \pm 0$ & $0.39 \pm 0.06$ & $0.39 \pm 0.06$ & $2.09 \pm 0.05$ & $3.75 \pm 0.12$ & $1.66 \pm 0.12$ \\
GMTED_GRID & $0.19 \pm 0.02$ & $0.34 \pm 0.01$ & $0.15 \pm 0.02$ & $0 \pm 0$ & $0.38 \pm 0.06$ & $0.38 \pm 0.06$ & $1.80 \pm 0.05$ & $3.32 \pm 0.13$ & $1.52 \pm 0.13$ \\
HYDRO1k_BASIN & $0.25 \pm 0.02$ & $0.37 \pm 0.01$ & $0.12 \pm 0.01$ & $0 \pm 0$ & $0.39 \pm 0.06$ & $0.39 \pm 0.06$ & $2.44 \pm 0.05$ & $4.32 \pm 0.11$ & $1.89 \pm 0.11$ \\
HYDRO1k_GRID & $0.22 \pm 0.02$ & $0.36 \pm 0.01$ & $0.14 \pm 0.02$ & $0 \pm 0$ & $0.36 \pm 0.07$ & $0.36 \pm 0.07$ & $2.12 \pm 0.05$ & $3.73 \pm 0.13$ & $1.61 \pm 0.13$ \\
Average & $0.27 \pm 0.04$ & $0.38 \pm 0.02$ & $0.11 \pm 0.01$ & $0 \pm 0$ & $0.40 \pm 0.04$ & $0.40 \pm 0.04$ & $2.49 \pm 0.65$ & $4.37 \pm 0.99$ & $1.88 \pm 0.35$ \\
\hline Observations & & & & & & & & & \\
\hline Hess2015 & 0.23 & 0.58 & & & & & & \\
GIEMS & $0.12 \pm 0.01$ & $0.25 \pm 0.03$ & $0.14 \pm 0.04$ & $0 \pm 0$ & $0.24 \pm 0.05$ & $0.25 \pm 0.05$ & $1.38 \pm 0.09$ & $4.47 \pm 0.20$ & $3.09 \pm 0.19$ \\
SWAMPS-GLWD & $0.22 \pm 0.03$ & $0.34 \pm 0.01$ & $0.12 \pm 0.03$ & $0 \pm 0$ & $0.50 \pm 0.03$ & $0.51 \pm 0.03$ & $3.03 \pm 0.13$ & $6.62 \pm 0.18$ & $3.63 \pm 0.14$ \\
\hline
\end{tabular}
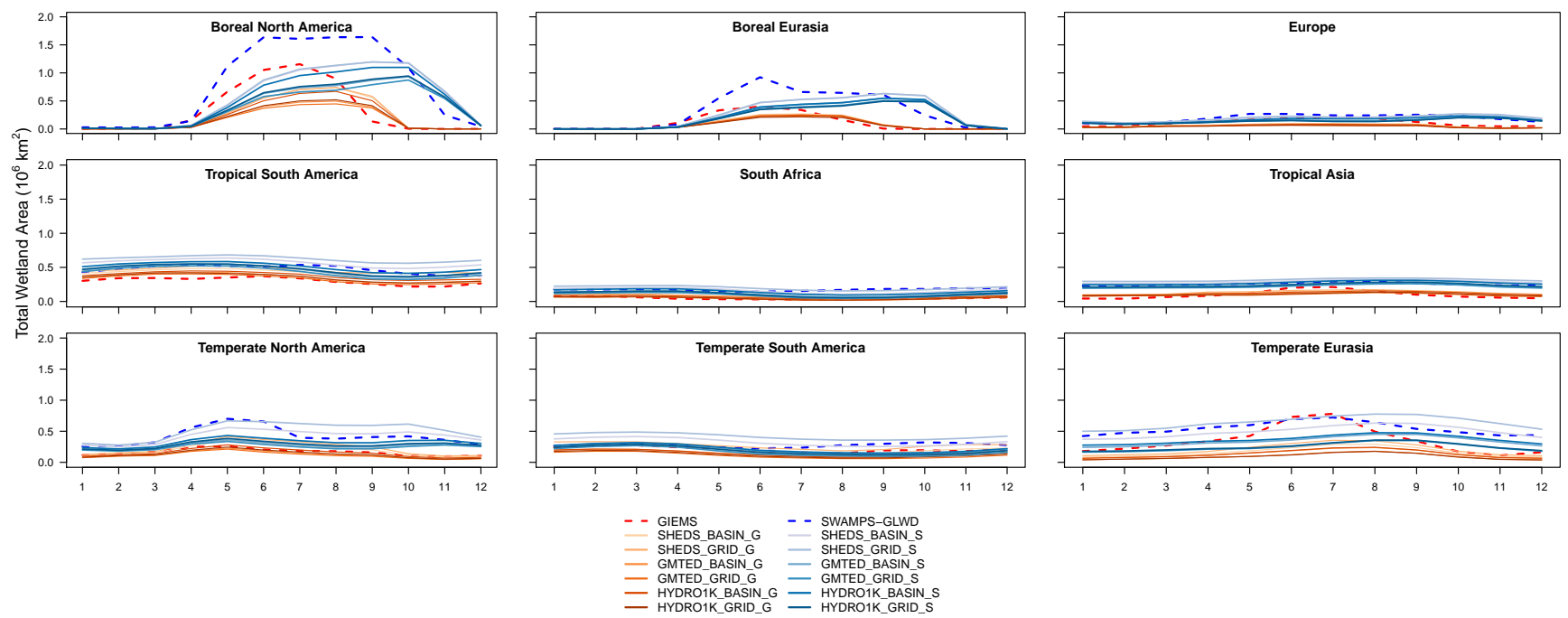

Figure 8. Average seasonal variability of observed and simulated monthly total wetland area for Transcom regions (see Fig. 2). For consistent comparison, two sets of simulated results were generated by masking out pixels for which GIEMS (red, dashed) or SWAMPS-GLWD (blue, dashed) do not have observations (denoted as '-G' and '-S', respectively).

rameterization show the same general behavior in the different regions. The six data sets are highly correlated, with largest differences at the maximal wetland extents during growing seasons, especially in the boreal regions. In addition, the differences in seasonal cycle among the six model experiments are relatively small, mostly below $5 \%$ regardless of the month. This indicates that the averaged total wetland area is not dependent on the introduction of the new sub-grid parameterizations at the global scale. Among the DEM data sets, HYDRO1k shows the largest difference between basin and grid-based estimates with annual mean wetland area of $89663 \mathrm{~km}^{2}$ in boreal regions, while HydroSHEDS has the lowest difference of $6550 \mathrm{~km}^{2}$ between the two versions. Examining the seasonal amplitude for basin-based schemes,
HydroSHEDS shows a better agreement with satellite-based observations than the other two data sets.

\subsection{Interannual variability}

To evaluate the performance of all the sub-grid parameterizations, we calculated the Pearson's correlation coefficient $(r)$ between modeled and satellite-based results (Table 4). Generally, the comparison demonstrates that simulated interannual variability shows a good agreement with GIEMS and SWAMPS-GLWD in most regions as defined in Fig. 2. For boreal and tropical regions, all correlation coefficients range from 0.7 to 0.8 . The comparison of the interannual trends (Fig. A1 in the Appendix) indicates that absolute values of simulated interannual variations are close to satellite-based 
observation with good agreement in shape and timing in these regions. This demonstrates the ability of TOPMODEL to capture the large-scale variations in wetland/inundation. The highest disagreements are found in temperate regions that are strongly affected by human activities (likely a strong global anthropogenic effect on continental surface freshwater), which is indicated by GIEMS (Prigent et al., 2012) but not by modeled results.

The interannual variability originating from six different sub-grid DEM parameterizations of these schemes is very similar, with Spearman rank correlation coefficient $r>90 \%$. Among the six schemes, the parameters calculated from HydroSHEDS using basin-based statistics result in better agreement between simulated and measured wetland area than the other schemes. In most regions, the SWAMPS-GLWD and GIEMS are consistent in their observed wetland area patterns, except for temperate regions (e.g., temperate South America, temperate North America, Europe). This confirms that the differences in surface water extend detection between GIEMS and SWAMPS-GLWD, which might be caused by observational behaviors from different satellite instruments and algorithms. In addition, parameters estimation based on river basins are slightly better than grid-based results.

\section{Discussion}

\subsection{Wetland modeling based on TOPMODEL concept}

The coupling of LPJ-wsl with TOPMODEL with calibrated parameters as described in this study, improves the dynamic simulation of wetlands, in particular their geographic location and extent. This is based on the recent discussions of the suitability of TOPMODEL applications to simulate wetland variations at large spatial scale (Ringeval et al., 2012), and intercomparisons of the wetland-area-driven model bias in $\mathrm{CH}_{4}$ emission at regional scale (Bohn et al., 2015). The large discrepancies of wetland area among LSMs so far have shown extensive disagreement with inventories and remotely sensed inundation data sets (Melton et al., 2013), which is partly due to large varieties of schemes used for representing hydrological processes, or due to the inappropriate parameterizations for simulating inundations. Our results suggest that benchmarking $F_{\max }$ is necessary for global wetland modeling.

The simulation of hydrological dynamics within LSMs remains relatively simple because the physical processes described in LSMs occur at much finer spatial scales (Ducharne, 2009; Mulligan and Wainwright, 2013). The coupling of TOPMODEL with process-based LSMs allows for retrieving of the maximum saturated fraction $\left(F_{\max }\right)$, which is defined by the pixels with no water deficit estimated from the partial integration of the spatial distribution of CTI in a catchment. The estimated distribution of $F_{\max }$ is much larger than that obtained from the satellite-based observations (Papa et al., 2010). As a key parameter for determining the soil saturated area, the calculation of $F_{\max }$ at large scale is prone to large uncertainties, in particular linked to uncertainties in topographic information, as well as the hydrological processes implemented in large-scale LSMs. Ringeval et al. (2012) pointed to the difficulty of two-layer bucket hydrological model in estimating the mean deficit to the saturation over each grid cell. This can lead to nonrealistic absolute values of the contributing area in a watershed. We constructed several strategies for optimizing $F_{\max }$ by correcting topographic information to match the wetland inventories (Gedney and Cox, 2003; Kleinen et al., 2012). This is one possible solution for global wetland modeling as it assumes that wetland area can be considered constant at coarse spatial resolution (e.g., 0.5 or $1^{\circ}$ ), following the classical approach of Beven and Kirkby (1979). However, due to the uncertainties from topographic information used in global applications and due to limitations in model parameterizations, this approximation cannot capture the fine-scale wetland extent, which complicates the comparison with inventories.

The integration of satellite-based and inventory-based observations to calibrate $F_{\max }$ is highlighted in this study. Combining SWAMPS and GLWD led to simulated wetland area consistent with detailed regional distribution (Poulter et al., 2015). Our estimation of global wetland potential/maximum is $\sim 10.3 \mathrm{Mkm}^{2}$ and in agreement with the deduction $\left(10.4 \mathrm{Mkm}^{2}\right)$ from recent estimates at finer resolution for total open water $\left(\sim 17.3 \mathrm{Mkm}^{2}\right)$ (Fluet-Chouinard et al., 2015), lakes $\left(\sim 5 \mathrm{Mkm}^{2}\right)$ (Verpoorter et al., 2014), and rice paddies $\left(1.9 \mathrm{Mkm}^{2}\right)$ (Leff et al., 2004). The calibration of $F_{\max }$ allows for simulating the dynamics of wetland on decade-to-century-long timescales. As shown in Fig. 9, the wetland potential for permafrost and arid/semi-arid regions is high. Even in tropical regions, there is $\sim 20-30 \%$ of potential for areas to be inundated.

According to our evaluation using satellite-based observations and inventories, the spatial distribution of the wetland areas and its temporal variability are generally well captured by our model, both at regional and global scales. In addition, the modeled wetland areas and interannual variability compare well with inventories and satellite-based observations, respectively. Unfortunately, the wide disagreement in simulated wetland dynamics among estimates from WETCHIMP hampers our ability to assess model performance (Bohn et al., 2015). Narrowing down the uncertainty of wetland areas by existing maps could minimize the controversial use of the definition between wetlands and inundations. Wetlands have considerable variations in hydrologic conditions, size, locations that make it difficult to reconcile a single definition of wetlands. In current parameterizations, the connectivity of wetlands cannot be represented since wetlands are considered invariant within grid cells. 
Table 4. Spearman correlations between satellite-based vs. modeled interannual anomalies of the grid cells contained in each region defined in Fig. 2f at global scale. Values out and in parentheses are correlation efficient with SWAMPS-GLWD and GIEMS, respectively. The two highest values within one column are in bold.

\begin{tabular}{|c|c|c|c|c|c|c|}
\hline Regions & $\begin{array}{l}\text { SHDES } \\
\text { BASIN }\end{array}$ & $\begin{array}{l}\text { SHDES } \\
\text { GRID }\end{array}$ & $\begin{array}{l}\text { GMTED } \\
\text { BASIN }\end{array}$ & $\begin{array}{l}\text { GMTED } \\
\text { GRID }\end{array}$ & $\begin{array}{l}\text { HYDRO1K } \\
\text { BASIN }\end{array}$ & $\begin{array}{l}\text { HYDRO1k } \\
\text { GRID }\end{array}$ \\
\hline Boreal North America & $\begin{array}{l}0.770 \\
(0.378)\end{array}$ & $\begin{array}{l}\mathbf{0 . 7 6 8} \\
(0.376)\end{array}$ & $\begin{array}{l}0.751 \\
(0.354)\end{array}$ & $\begin{array}{l}0.745 \\
(0.341)\end{array}$ & $\begin{array}{l}0.765 \\
(\mathbf{0 . 3 7 8 )}\end{array}$ & $\begin{array}{l}0.748 \\
(0.343)\end{array}$ \\
\hline Boreal Eurasia & $\begin{array}{l}0.785 \\
(0.513)\end{array}$ & $\begin{array}{l}0.782 \\
(0.511)\end{array}$ & $\begin{array}{l}0.763 \\
(0.487)\end{array}$ & $\begin{array}{l}0.764 \\
(0.487)\end{array}$ & $\begin{array}{l}0.763 \\
(0.493)\end{array}$ & $\begin{array}{l}0.760 \\
(0.484)\end{array}$ \\
\hline Europe & $\begin{array}{l}0.604 \\
(0.091)\end{array}$ & $\begin{array}{l}\mathbf{0 . 5 9 5} \\
(0.079)\end{array}$ & $\begin{array}{l}0.313 \\
(-0.198)\end{array}$ & $\begin{array}{l}0.211 \\
(-\mathbf{0 . 2 7 8})\end{array}$ & $\begin{array}{l}0.588 \\
(0.076)\end{array}$ & $\begin{array}{l}0.218 \\
(-\mathbf{0 . 2 7 2})\end{array}$ \\
\hline Tropical South America & $\begin{array}{l}0.723 \\
(\mathbf{0 . 8 3 8})\end{array}$ & $\begin{array}{l}\mathbf{0 . 7 2 5} \\
(0.831)\end{array}$ & $\begin{array}{l}0.724 \\
(0.835)\end{array}$ & $\begin{array}{l}0.666 \\
(0.825)\end{array}$ & $\begin{array}{l}0.708 \\
(\mathbf{0 . 8 3 6})\end{array}$ & $\begin{array}{l}\mathbf{0 . 7 2 6} \\
(0.835)\end{array}$ \\
\hline South Africa & $\begin{array}{l}0.082 \\
(\mathbf{0 . 7 3 6 )}\end{array}$ & $\begin{array}{l}0.044 \\
(0.725)\end{array}$ & $\begin{array}{l}\mathbf{0 . 0 8 4} \\
(0.735)\end{array}$ & $\begin{array}{l}0.076 \\
(0.734)\end{array}$ & $\begin{array}{l}0.040 \\
(0.717)\end{array}$ & $\begin{array}{l}0.088 \\
(0.740)\end{array}$ \\
\hline Tropical Asia & $\begin{array}{l}0.689 \\
(0.674)\end{array}$ & $\begin{array}{l}\mathbf{0 . 6 8 1} \\
(0.673)\end{array}$ & $\begin{array}{l}0.705 \\
(\mathbf{0 . 6 8 2})\end{array}$ & $\begin{array}{l}0.677 \\
(0.625)\end{array}$ & $\begin{array}{l}0.670 \\
(0.660)\end{array}$ & $\begin{array}{l}0.648 \\
(0.632)\end{array}$ \\
\hline Temperate North America & $\begin{array}{l}0.359 \\
(0.139)\end{array}$ & $\begin{array}{l}0.380 \\
(0.155)\end{array}$ & $\begin{array}{l}0.406 \\
(0.262)\end{array}$ & $\begin{array}{l}0.347 \\
(0.229)\end{array}$ & $\begin{array}{l}0.518 \\
(0.288)\end{array}$ & $\begin{array}{l}0.479 \\
(0.305)\end{array}$ \\
\hline Temperate South America & $\begin{array}{l}-0.193 \\
(0.633)\end{array}$ & $\begin{array}{l}-\mathbf{0 . 2 0 5} \\
(0.597)\end{array}$ & $\begin{array}{l}-0.153 \\
(0.622)\end{array}$ & $\begin{array}{l}-0.162 \\
(\mathbf{0 . 6 4 1})\end{array}$ & $\begin{array}{l}-0.178 \\
(0.627)\end{array}$ & $\begin{array}{l}-0.166 \\
(0.627)\end{array}$ \\
\hline Temperate Eurasia & $\begin{array}{l}0.742 \\
(0.645)\end{array}$ & $\begin{array}{l}0.760 \\
(0.660)\end{array}$ & $\begin{array}{l}0.735 \\
(0.642)\end{array}$ & $\begin{array}{l}0.721 \\
(0.643)\end{array}$ & $\begin{array}{l}0.732 \\
(0.642)\end{array}$ & $\begin{array}{l}0.716 \\
(0.642\end{array}$ \\
\hline
\end{tabular}

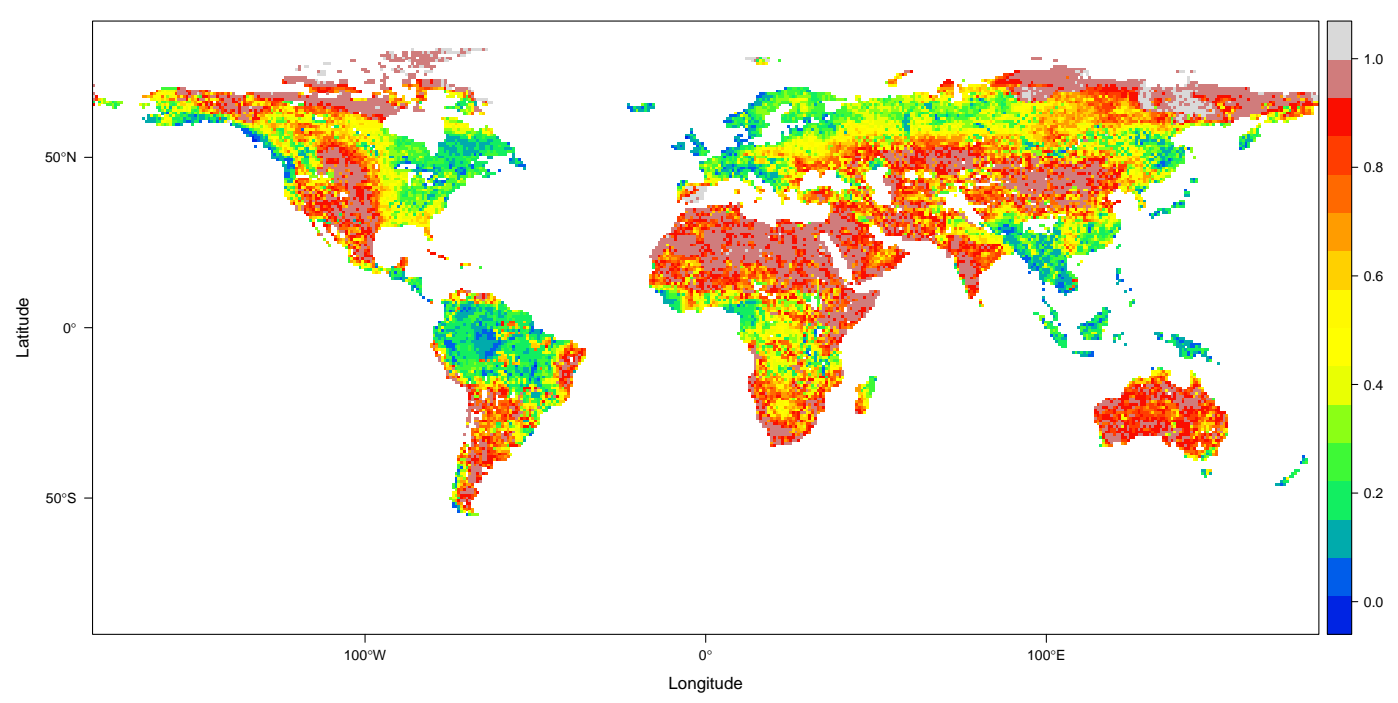

Figure 9. Global wetland potential map, which is calculated by the ratio of the mean annual maximum wetland extent averaged for the time period 1980-2010 and the long-term potential maximum wetland area $\left(\mathrm{F}_{\max }^{\mathrm{wet}}\right)$. Higher value represents higher availability for sub-grids to be inundated.

\subsection{CTI parameterizations}

As shown in this study, global wetland simulations can benefit from improved spatial resolution of topographic maps, thus creating a more realistic representation of processes at sub-grid resolution and correspondingly better inundation simulations. This is supporting the ideas of Wood et al. (2011) who claimed that higher-resolution modeling leads to better spatial representation of saturated and nonsaturated areas, even though limitations in up-scaling parameterizations may potentially outrun this advantage. The comparison between HydroSHEDS and GMTED also indicated that, for capturing inundated areas under the same spatial resolution, the parameter maps derived from DEM without hydrological corrections have less accuracy compared to corrected ones (Lehner and Grill, 2013). Without hydrological corrections, valleys would appear as closed depressions in 
the DEM, leading to an underestimation of inundated areas (Marthews et al., 2015). It could be foreseen that if DEMs in process-based models are being applied at higher resolution, this drawback could be amplified. The comparison between basin- and grid-based parameterizations suggests that grid-based calculations are not appropriate and consequently underestimates wetland areas even when assuming invariant inundated areas at large scale.

The algorithm to calculate CTI is another potential source of error for modeling inundations. The method we applied here is based on calculating a CTI distribution map using a simple algorithm in the R package "topmodel" instead of using an existing CTI product with improved contributing area. The algorithm we applied using the multi-flow direction algorithm that allows for multiple in-flow and out-flow of water among neighboring pixels when generating topographic values. This could potentially overestimate the contributing areas (Pan et al., 2004). As a result, it might underestimate the wetland areas within each grid cell and slightly underestimate the temporal pattern of saturated areas because of improper estimates of parameter $C_{\mathrm{s}}$ (Güntner et al., 2004). One limitation of HydroSHEDS is that its projection is not equal-area like HYDRO1k (Marthews et al., 2015) and will cause a potential bias in slope calculation along east-west directions at high latitudes. However, since there is no common method to calculate slope or flow direction, we believe that our calculations provide a reasonable approximation for global applications.

In addition, variability in TOPMODEL parameterizations have considerable influence on simulated $\mathrm{CH}_{4}$ fluxes, so that the uncertainty of mean annual $\mathrm{CH}_{4}$ emissions from variable topography inputs is estimated to be $29.0 \mathrm{Tg} \mathrm{yr}^{-1}$ (Table 5). Nevertheless, all of the model estimates generally fall within the value range of inversion estimates. The differences of $\mathrm{CH}_{4}$ emissions among the model experiments is related to simulated magnitude of wetland extents because the fraction of $\mathrm{CH}_{4}$ emissions from the tropics $(\sim 63 \%)$ and extratropics $(\sim 27 \%)$ remains constant due to the same parameters $r_{\mathrm{C}: \mathrm{CH}_{4}}$ and $f_{\text {ecosys }}$. The importance of hydrological correction is highlighted by results based on GMTED, suggesting that applying DEMs without hydro-correction may potentially underestimate $\mathrm{CH}_{4}$ fluxes due to lower hydrological connectivity, which dampen the generation of inundation. In addition, fine-scale topography data like HydroSHEDS reveal higher $\mathrm{CH}_{4}$ fluxes than HYDRO1k, highlighting the importance of capturing small wetlands/inundated areas that may be ignored by coarse-resolution products.

\subsection{Future needs for global wetland modeling}

Substantial progress has been made in the development of wetland modeling, but the wide disagreement among estimates from LSMs still exists (Bohn et al., 2015; Melton et al., 2013). Considering that spatiotemporal variation of wetland area can largely influence $\mathrm{CH}_{4}$ emissions, the selection of ap- propriate maps needs to be done with care. The parameterization and evaluation of multi-resolution topographic products presented in this study would enhance global wetland modeling if progress could be made in the following four areas.

\subsubsection{Improved parameters of TOPMODEL for large-scale application}

Our results demonstrate that model simulation after calibrating TOPMODEL are comparable in absolute value with inventories and satellite-based observations at coarser resolution. This supports the ideas of Beven and Cloke (2012) that an appropriate scale-dependent subgrid parameterization is the main challenge, regardless of whether it is carried out at global modeling scales or landscape scales. The saturated soil water content is the decisive unit that determines wetland distributions and reasonable estimates of global wetland areas. Hydraulic parameters, which describe soil characteristics for water movement, are critical for modeling wetland seasonal cycles (Marthews et al., 2014). Assessing the uncertainties introduced by aggregating sub-pixel to pixel areas also need to be evaluated.

\subsubsection{Implementing human impact within wetland modeling}

There is evidence from long-term satellite-based observations of a significant effect of human activities on wetland drainage at continental scale (Prigent et al., 2012). At finer scale, the variability of wetland extent has also been affected by land-use change (e.g., wetland restoration, deforestation, drainage for forestry, agriculture, or peat mining) and consequently influences spatiotemporal patterns of $\mathrm{CH}_{4}$ emission (Petrescu et al., 2015; Zona et al., 2009). Land-use change may therefore add feedback water available to wetlands through altering water balance between land surface and atmosphere (Woodward et al., 2014). An implementation of human impacts within LSMs at large scale may be important for accurate estimation of interannual variations of wetlands.

\subsubsection{Improved modeling of soil moisture}

The quality of soil moisture simulation using LSMs depends largely on the accuracy of the meteorological forcing data, surface-atmosphere interaction schemes, and a wide range of parameters (Zhang et al., 2013) (e.g., $\mathrm{CO}_{2}$ concentration, albedo, minimum stomatal resistance, and soil hydraulic properties). As the fundamental variable for determining water table depth at global scale (Fan et al., 2013), soil moisture plays a key role in simulating the spatiotemporal variability of wetland dynamics. Since it is impossible to produce accurate large-scale estimates of soil moisture from in situ measurement networks (Bindlish et al., 2008; Dorigo et al., 2011), simulation combined with long-term surface and root zone remotely sensed estimates (de Rosnay et al., 2013; Kerr 
Table 5. List of global and regional wetland $\mathrm{CH}_{4}$ estimates from our model experiments (see Table 2) over the period 1980-2000. All units are $\mathrm{Tg} \mathrm{CH}_{4} \mathrm{yr}^{-1} \pm 1 \sigma$, where standard deviation represents the interannual variation in the model estimates. Note that estimates from some reference studies are not for the same period.

\begin{tabular}{|c|c|c|c|c|c|c|c|c|}
\hline \multirow[t]{2}{*}{ Estimates } & \multirow[t]{2}{*}{ Global } & \multicolumn{3}{|c|}{ Regions } & \multicolumn{4}{|c|}{ Hotspot } \\
\hline & & $\begin{array}{l}\text { Tropics } \\
\left(20^{\circ} \mathrm{N} \text { to } 30^{\circ} \mathrm{S}\right)\end{array}$ & $\begin{array}{l}\text { Temperate } \\
\left(20-45^{\circ} \mathrm{N}, 30-50^{\circ} \mathrm{S}\right)\end{array}$ & $\begin{array}{l}\text { Northern } \\
\left(>45^{\circ} \mathrm{N}\right)\end{array}$ & $\begin{array}{l}\text { Central } \\
\text { Amazon }^{\mathrm{b}}\end{array}$ & WSL & Hudson Bay & Alaska \\
\hline SHEDS_BASIN & 171.9 & $109.3 \pm 2.3$ & $26.4 \pm 1.0$ & $36.1 \pm 1.8$ & $10.9 \pm 0.3$ & $5.4 \pm 0.9$ & $6.5 \pm 0.5$ & $1.7 \pm 0.3$ \\
\hline SHEDS_GRID & 193.0 & $123.7 \pm 2.2$ & $31.4 \pm 1.0$ & $38.7 \pm 1.9$ & $11.4 \pm 0.3$ & $5.5 \pm 0.9$ & $7.1 \pm 0.6$ & $1.5 \pm 0.3$ \\
\hline GMTED_BASIN & 130.1 & $85.5 \pm 2.3$ & $19.0 \pm 0.9$ & $26.3 \pm 1.4$ & $9.5 \pm 0.4$ & $4.5 \pm 0.9$ & $4.4 \pm 0.6$ & $1.6 \pm 0.3$ \\
\hline GMTED_GRID & 117.2 & $76.7 \pm 2.3$ & $16.4 \pm 0.9$ & $24.2 \pm 1.4$ & $9.2 \pm 0.4$ & $4.1 \pm 0.9$ & $4.2 \pm 0.6$ & $1.4 \pm 0.3$ \\
\hline HYDRO1K_BASIN & 148.3 & $96.4 \pm 2.3$ & $21.5 \pm 0.9$ & $30.3 \pm 1.6$ & $10.4 \pm 0.3$ & $4.4 \pm 0.9$ & $5.8 \pm 0.6$ & $1.7 \pm 0.3$ \\
\hline HYDRO1K_GRID & 128.8 & $85.0 \pm 2.3$ & $17.8 \pm 0.9$ & $26.0 \pm 1.4$ & $10.0 \pm 0.4$ & $3.9 \pm 0.9$ & $4.8 \pm 0.6$ & $1.5 \pm 0.3$ \\
\hline Melton et al. (2013) ${ }^{\mathrm{a}}$ & $190 \pm 39$ & & & & & & $5.4 \pm 3.2$ & \\
\hline Zhu et al. (2015) & $209-245$ & & & $38.1-55.4$ & & & & \\
\hline Chen et al. (2015) & & & & 35 & & & $3.11 \pm 0.45$ & \\
\hline Zhu et al. (2014) & & & & $34-58$ & & & $3.1 \pm 0.5$ & \\
\hline Ringeval et al. (2012) & 193.8 & 102 & 51 & 40.8 & & & & \\
\hline Glagolev et al. (2011) & & & & & & $3.91 \pm 1.3$ & & \\
\hline Melack et al. (2004) & & & & & 9.1 & & & \\
\hline Zhuang et al. (2004) & & & & 57.3 & & & & \\
\hline Chang et al. (2014) & & & & & & & & $2.1 \pm 0.5$ \\
\hline Bloom et al. (2012) & & 111.1 & & & & & & \\
\hline Bousquet et al. (2011) & $151 \pm 10$ & $91 \pm 11$ & & & & & & \\
\hline Bloom et al. (2010) & $165 \pm 50$ & $91 \pm 28$ & & & & & $4.9 \pm 1.4$ & \\
\hline
\end{tabular}

${ }^{\mathrm{a}}$ WETCHIMP estimates for $1993-2004 .{ }^{\mathrm{b}}$ Central Amazon $\left(54-72^{\circ} \mathrm{W}, 0-8^{\circ} \mathrm{S}\right)$.

et al., 2010) via data assimilation technology represents a strategy to improve the capturing of global wetland variability. Future hydrology-oriented satellite missions such as Soil Moisture Active Passive (SMAP) (Entekhabi et al., 2010) and Surface Water and Ocean Topography (SWOT) (Durand et al., 2010) are expected to provide soil moisture and will improve the capacity of global soil moisture simulations.

\subsubsection{Improved satellite benchmark observations}

Current satellite-based estimates of wetland area remain generally uncertain, despite being important for monitoring global wetland variability. Remotely sensed global inundation is prone to underestimate small wetlands, as well as canopies covered with dense vegetation (Papa et al., 2010). Moreover, estimated coastal areas show large bias due to interference with the ocean surface (Prigent et al., 2007). This raises the need for a benchmark data set to generate accurate products with lower uncertainties. Downscaling methodology has been made to refine existing satellite-based inundation estimates by coupling the mapping process with reliable inventories (Fluet-Chouinard et al., 2015). This may improve global inundation products, as well as the TOPMODEL parameter estimation in the future.

\section{Conclusion}

The new LPJ-wsl version incorporates a TOPMODEL approach and a permafrost module representing soil freeze- thaw processes to simulate global wetland dynamics. Once the $F_{\max }$ parameter in TOPMODEL was calibrated against a benchmark data set, the model successfully mapped regional spatial pattern of wetlands in West Siberian Lowland and the lowland Amazon basin and captured well the spatiotemporal variations of global wetlands. The parameterization of TOPMODEL based on three DEM products, HYDRO1k, GMTED, and HydroSHEDS, revealed that HydroSHEDS performed best in capturing the spatial heterogeneity and interannual variability of inundated areas compared to inventories. River-basin-based parameterization schemes using HYDRO1k and GMTED marginally but significantly improve wetland area estimates. The estimates of global wetland potential/maximum is $\sim 10.3 \mathrm{Mkm}^{2}$, with a mean annual maximum of $\sim 5.17 \mathrm{Mkm}^{2}$ for 1980-2010. This development of the wetland modeling method reduces the uncertainties in modeling global wetland area and opens up new opportunities for studying the spatiotemporal variability of wetlands in LSMs that are directly comparable with inventories and satellite data sets. 


\section{Appendix A}
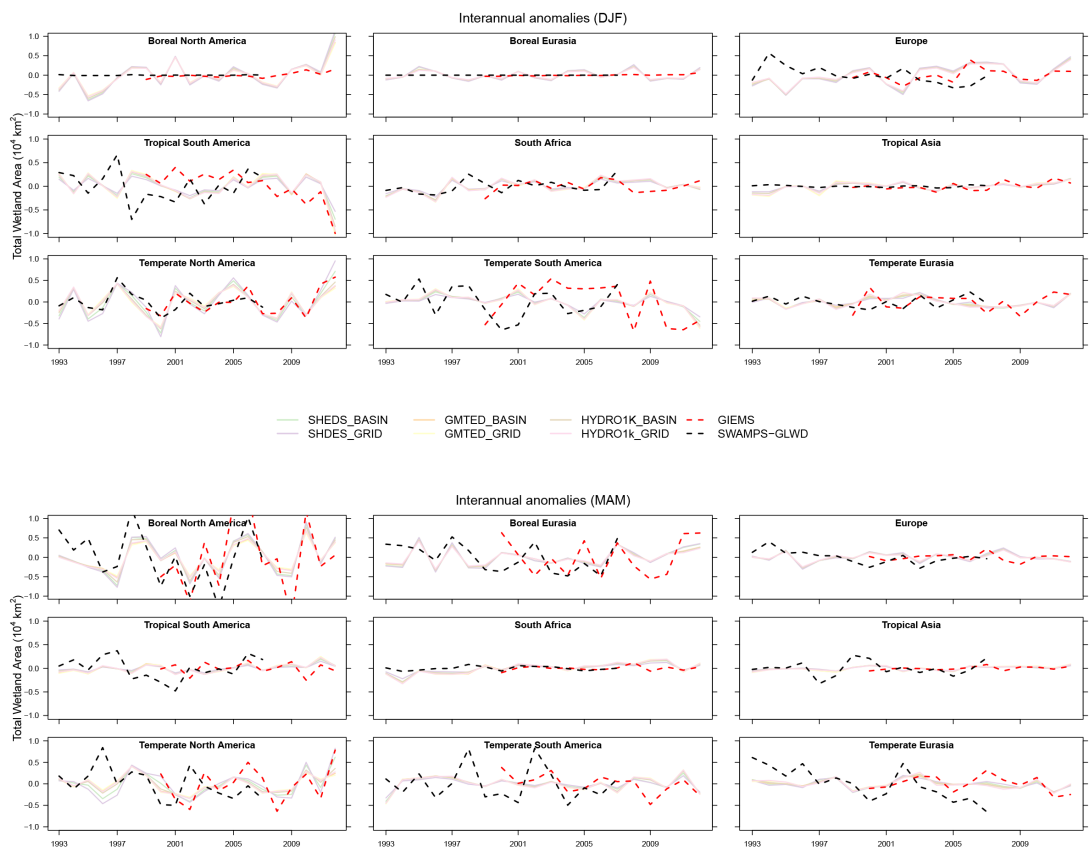

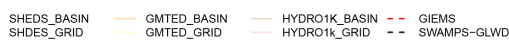
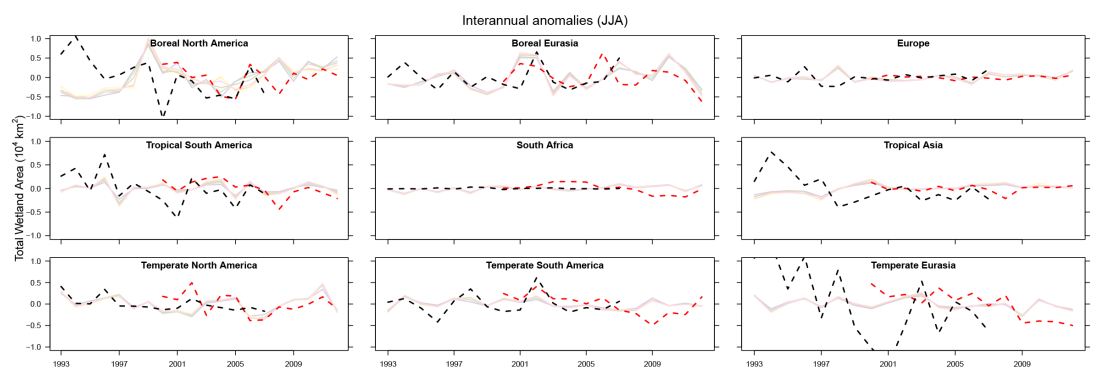

SHEDS_BASIN
SHDES_GRID

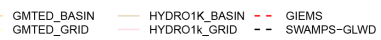
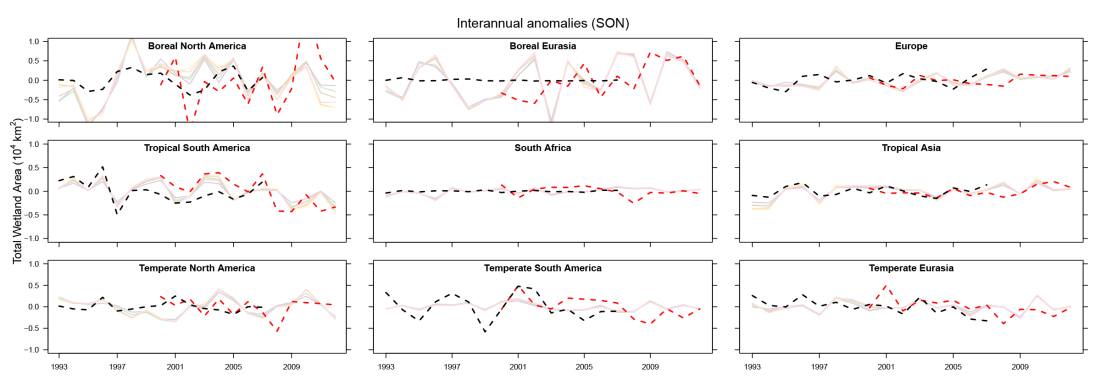

SHEDS_BASI

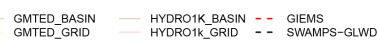

Figure A1. Interannual variations of seasonal wetland area anomalies from LPJ-wsl and satellite-derived observations for the period 19932012. 
Table A1. Reclassification table for aggregating JERS-1 lowland Amazon basin to $0.5^{\circ}$ cell. Codes NA, 0,1 , and 2 refer to, respectively, not-available, non-wetland, wetland that exists only in low-water season, and wetland that exists in high-water season.

\begin{tabular}{|c|c|c|c|}
\hline $\mathrm{DN}$ & $\begin{array}{l}\text { Cover at } \\
\text { low-water stage }\end{array}$ & $\begin{array}{l}\text { Cover at } \\
\text { higher-water stage }\end{array}$ & $\begin{array}{l}\text { Flag for } \\
\text { minimum/maximum wetlands }\end{array}$ \\
\hline 0 & Land outside Amazon basin & Land outside Amazon basin & NA \\
\hline 1 & Non-wetland within Amazon basin & Non-wetland within Amazon basin & 0 \\
\hline 11 & Open water & Open water & 0 \\
\hline 13 & Open water & Aquatic macrophyte & 0 \\
\hline 21 & Bare soil or herbaceous, non-flooded & Open water & 2 \\
\hline 23 & Bare soil or herbaceous, non-flooded & Aquatic macrophyte & 2 \\
\hline 33 & Aquatic macrophyte & Aquatic macrophyte & 1 \\
\hline 41 & Shrub, non-flooded & Open water & 2 \\
\hline 44 & Shrub, non-flooded & Shrub, non-flooded & 0 \\
\hline 45 & Shrub, non-flooded & Shrub, flooded & 2 \\
\hline 51 & Shrub, flooded & Open water & 1 \\
\hline 55 & Shrub, flooded & Shrub, flooded & 1 \\
\hline 66 & Woodland, non-flooded & Woodland, non-flooded & 0 \\
\hline 67 & Woodland, non-flooded & Woodland, flooded & 2 \\
\hline 77 & Woodland, flooded & Woodland, flooded & 1 \\
\hline 88 & Forest, non-flooded & Forest, non-flooded & 0 \\
\hline 89 & Forest, non-flooded & Forest, flooded & 2 \\
\hline 99 & Forest, flooded & Forest, flooded & 1 \\
\hline 200 & Elevation $>=500 \mathrm{~m}$, in basin & Elevation $>=500 \mathrm{~m}$, in basin & NA \\
\hline 255 & Ocean & Ocean & NA \\
\hline
\end{tabular}


Acknowledgements. Z. Zhang acknowledges funding by the CCES MAIOLICA2 project no. 42-01 and the National Natural Science Foundation of China (Y411391001). J. O. Kaplan was supported by the European Research Council (313797 COEVOLVE). We are grateful to T. J. Bohn for providing WETCHIMP-WSL experiment results. We thank B. D. Stocker for providing HYDRO1K global river-basin map, T. Marthews for providing global CTI data set of HydroSHEDS, and L. L. Hess for the results of dual-season inundated product of the lowland Amazon basin.

Edited by: F. Wittmann

\section{References}

Air Force Weather Agency: Data Format Handbook for AGRMET, technical report, Air Force Weather Agency's (AFWA) Agricultural Metereorological modeling system (AGRMET), Air Force Weather Agency, available at: http://www2.mmm.ucar. edu/mm5/documents/DATA_FORMAT_HANDBOOK.pdf (last access: July 2014), 2002.

Bergamaschi, P., Frankenberg, C., Meirink, J. F., Krol, M., Dentener, F., Wagner, T., Platt, U., Kaplan, J. O., Körner, S., Heimann, M., Dlugokencky, E. J., and Goede, A.: Satellite chartography of atmospheric methane from SCIAMACHY on board ENVISAT: 2. Evaluation based on inverse model simulations, J. Geophys. Res.-Atmos., 112, D02304, doi:10.1029/2006JD007268, 2007.

Beven, K. J. and Cloke, H. L.: Comment on "Hyperresolution global land surface modeling: Meeting a grand challenge for monitoring Earth's terrestrial water" by Eric F. Wood et al., Water Resour. Res., 48, W01801, doi:10.1029/2011WR010982, 2012.

Beven, K. J. and Kirkby, M. J.: A physically based, variable contributing area model of basin hydrology/Un modèle à base physique de zone d'appel variable de l'hydrologie du bassin versant, Hydrological Sciences Bulletin, 24, 43-69, 1979.

Bindlish, R., Jackson, T. J., Gasiewski, A., Stankov, B., Klein, M., Cosh, M. H., Mladenova, I., Watts, C., Vivoni, E., Lakshmi, V., Bolten, J., and Keefer, T.: Aircraft based soil moisture retrievals under mixed vegetation and topographic conditions, Remote Sens. Environ., 112, 375-390, 2008.

Bloom, A. A., Palmer, P. I., Fraser, A., Reay, D. S., and Frankenberg, C.: Large-Scale Controls of Methanogenesis Inferred from Methane and Gravity Spaceborne Data, Science, 327, 322-325, 2010.

Bloom, A. A., Palmer, P. I., Fraser, A., and Reay, D. S.: Seasonal variability of tropical wetland $\mathrm{CH}_{4}$ emissions: the role of the methanogen-available carbon pool, Biogeosciences, 9, 28212830, doi:10.5194/bg-9-2821-2012, 2012.

Bohn, T. J., Melton, J. R., Ito, A., Kleinen, T., Spahni, R., Stocker, B. D., Zhang, B., Zhu, X., Schroeder, R., Glagolev, M. V., Maksyutov, S., Brovkin, V., Chen, G., Denisov, S. N., Eliseev, A. V., Gallego-Sala, A., McDonald, K. C., Rawlins, M.A., Riley, W. J., Subin, Z. M., Tian, H., Zhuang, Q., and Kaplan, J. O.: WETCHIMP-WSL: intercomparison of wetland methane emissions models over West Siberia, Biogeosciences, 12, 3321-3349, doi:10.5194/bg-12-3321-2015, 2015.

Bousquet, P., Ciais, P., Miller, J. B., Dlugokencky, E. J., Hauglustaine, D. A., Prigent, C., Van der Werf, G. R., Peylin, P., Brunke,
E. G., Carouge, C., Langenfelds, R. L., Lathiere, J., Papa, F., Ramonet, M., Schmidt, M., Steele, L. P., Tyler, S. C., and White, J.: Contribution of anthropogenic and natural sources to atmospheric methane variability, Nature, 443, 439-443, 2006.

Bousquet, P., Ringeval, B., Pison, I., Dlugokencky, E. J., Brunke, E.G., Carouge, C., Chevallier, F., Fortems-Cheiney, A., Frankenberg, C., Hauglustaine, D. A., Krummel, P. B., Langenfelds, R. L., Ramonet, M., Schmidt, M., Steele, L. P., Szopa, S., Yver, C., Viovy, N., and Ciais, P.: Source attribution of the changes in atmospheric methane for 2006-2008, Atmos. Chem. Phys., 11, 3689-3700, doi:10.5194/acp-11-3689-2011, 2011.

Brown, J., Ferrians Jr., O. J., Heginbottom J. A., and Melnikov, E. S.: Circum-arctic map of permafrost and ground ice conditions, edited by National Snow and Ice Data Center, Boulder, CO, USA, available at: http://nsidc.org/data/docs/fgdc/ggd318_ map_circumarctic/ (last access: December 2014), 2001.

Buytaert, W.: TOPMODEL, available at: http://cran.r-project.org/ web/packages/topmodel/index.html, last access: February 2015.

Chang, R. Y.-W., Miller, C. E., Dinardo, S. J., Karion, A., Sweeney, C., Daube, B. C., Henderson, J. M., Mountain, M. E., Eluszkiewicz, J., Miller, J. B., Bruhwiler, L. M. P., and Wofsy, S. C.: Methane emissions from Alaska in 2012 from CARVE airborne observations, P. Natl. Acad. Sci. USA, 111, 16694-16699, doi:10.1073/pnas.1412953111, 2014.

Chen, X., Bohn, T. J., and Lettenmaier, D. P.: Model estimates of climate controls on pan-Arctic wetland methane emissions, Biogeosciences, 12, 6259-6277, doi:10.5194/bg-12-6259-2015, 2015.

Glagolev, M., Kleptsova, I., Filippov, I., Maksyutov, S., and Machida, T.: Regional methane emission from West Siberia mire landscapes, Environ. Res. Lett., 6, 045214, doi:10.1088/17489326/6/4/045214, 2011.

Collins, W. J., Bellouin, N., Doutriaux-Boucher, M., Gedney, N., Halloran, P., Hinton, T., Hughes, J., Jones, C. D., Joshi, M., Liddicoat, S., Martin, G., O'Connor, F., Rae, J., Senior, C., Sitch, S., Totterdell, I., Wiltshire, A., and Woodward, S.: Development and evaluation of an Earth-System model - HadGEM2, Geosci. Model Dev., 4, 1051-1075, doi:10.5194/gmd-4-10512011, 2011.

Cosby, B. J., Hornberger, G. M., Clapp, R. B., and Ginn, T. R.: A Statistical Exploration of the Relationships of Soil Moisture Characteristics to the Physical Properties of Soils, Water Resour. Res., 20, 682-690, 1984.

Danielson, J. J. and Gesch, D. B.: Global Multi-resolution Terrain Elevation Data 2010, available at: http://topotools.cr.usgs.gov/ gmted_viewer/ (last access: September 2014), 2011.

de Rosnay, P., Drusch, M., Vasiljevic, D., Balsamo, G., Albergel, C., and Isaksen, L.: A simplified Extended Kalman Filter for the global operational soil moisture analysis at ECMWF, Q. J. Roy. Meteor. Soc., 139, 1199-1213, 2013.

Dorigo, W. A., Wagner, W., Hohensinn, R., Hahn, S., Paulik, C., Xaver, A., Gruber, A., Drusch, M., Mecklenburg, S., van Oevelen, P., Robock, A., and Jackson, T.: The International Soil Moisture Network: a data hosting facility for global in situ soil moisture measurements, Hydrol. Earth Syst. Sci., 15, 1675-1698, doi:10.5194/hess-15-1675-2011, 2011.

Ducharne, A.: Reducing scale dependence in TOPMODEL using a dimensionless topographic index, Hydrol. Earth Syst. Sci., 13, 2399-2412, doi:10.5194/hess-13-2399-2009, 2009. 
Ducharne, A., Koster, R. D., Suarez, M. J., and Kumar, P.: A catchment-based land surface model for GCMs and the framework for its evaluation, Phys. Chem. Earth, 24, 769-773, 1999.

Durand, M., Lee-Lueng, F., Lettenmaier, D. P., Alsdorf, D. E., Rodriguez, E., and Esteban-Fernandez, D.: The Surface Water and Ocean Topography Mission: Observing Terrestrial Surface Water and Oceanic Submesoscale Eddies, P. IEEE, 98, 766-779, 2010.

Entekhabi, D., Njoku, E. G., O’Neill, P. E., Kellogg, K. H., Crow, W. T., Edelstein, W. N., Entin, J. K., Goodman, S. D., Jackson, T. J., Johnson, J., Kimball, J., Piepmeier, J. R., Koster, R. D., Martin, N., McDonald, K. C., Moghaddam, M., Moran, S., Reichle, R., Shi, J. C., Spencer, M. W., Thurman, S. W., Leung, T., and Van Zyl, J.: The Soil Moisture Active Passive (SMAP) Mission, P. IEEE, 98, 704-716, 2010.

Fan, Y. and Miguez-Macho, G.: A simple hydrologic framework for simulating wetlands in climate and earth system models, Clim. Dynam., 37, 253-278, 2011.

Fan, Y., Li, H., and Miguez-Macho, G.: Global Patterns of Groundwater Table Depth, Science, 339, 940-943, 2013.

Fisher, R. E., Sriskantharajah, S., Lowry, D., Lanoisellé, M., Fowler, C. M. R., James, R. H., Hermansen, O., Lund Myhre, C., Stohl, A., Greinert, J., Nisbet-Jones, P. B. R., Mienert, J., and Nisbet, E. G.: Arctic methane sources: Isotopic evidence for atmospheric inputs, Geophys. Res. Lett., 38, L21803, doi:10.1029/2011GL049319, 2011.

Fluet-Chouinard, E., Lehner, B., Rebelo, L.-M., Papa, F., and Hamilton, S. K.: Development of a global inundation map at high spatial resolution from topographic downscaling of coarsescale remote sensing data, Remote Sens. Environ., 158, 348-361, 2015.

Gedney, N. and Cox, P. M.: The Sensitivity of Global Climate Model Simulations to the Representation of Soil Moisture Heterogeneity, J. Hydrometeorol., 4, 1265-1275, 2003.

Gerten, D., Schaphoff, S., Haberlandt, U., Lucht, W., and Sitch, S.: Terrestrial vegetation and water balance-hydrological evaluation of a dynamic global vegetation model, J. Hydrol., 286, 249-270, 2004.

Glagolev, M., Kleptsova, I., Filippov, I., Maksyutov, S., and Machida, T.: Regional methane emission from West Siberia mire landscapes, Environ. Res. Lett., 6, 045214, doi:10.1088/17489326/6/4/045214, 2011.

Grabs, T., Seibert, J., Bishop, K., and Laudon, H.: Modeling spatial patterns of saturated areas: A comparison of the topographic wetness index and a dynamic distributed model, J. Hydrol., 373, 15-23, 2009.

Gurney, K. R., Law, R. M., Denning, A. S., Rayner, P. J., Baker, D., Bousquet, P., Bruhwiler, L., Chen, Y.-H., Ciais, P., Fan, S., Fung, I. Y., Gloor, M., Heimann, M., Higuchi, K. A. Z., John, J., Kowalczyk, E. V. A., Maki, T., Maksyutov, S., Peylin, P., Prather, M., Pak, B. C., Sarmiento, J., Taguchi, S., Takahashi, T., and Yuen, C.-W.: TransCom $3 \mathrm{CO}_{2}$ inversion intercomparison: 1. Annual mean control results and sensitivity to transport and prior flux information, Tellus B, 55, 555-579, 2003.

Güntner, A., Seibert, J., and Uhlenbrook, S.: Modeling spatial patterns of saturated areas: An evaluation of different terrain indices, Water Resour. Res., 40, W05114, doi:10.1029/2003WR002864, 2004.
Harris, I., Jones, P. D., Osborn, T. J., and Lister, D. H.: Updated high-resolution grids of monthly climatic observations - the CRU TS3.10 Dataset, Int. J. Climatol., 34, 623-642, 2014.

Hess, L., Melack, J., Affonso, A., Barbosa, C., Gastil-Buhl, M., and Novo, E. L. M.: Wetlands of the Lowland Amazon Basin: Extent, Vegetative Cover, and Dual-season Inundated Area as Mapped with JERS-1 Synthetic Aperture Radar, Wetlands, 35, 1-12, doi:10.1007/s13157-015-0666-y, 2015.

Hodson, E. L., Poulter, B., Zimmermann, N. E., Prigent, C., and Kaplan, J. O.: The El Niño-Southern Oscillation and wetland methane interannual variability, Geophys. Res. Lett., 38, L08810, doi:10.1890/08-0588.1, 2011.

IPCC: Climate Change 2013: The Physical Science Basis. Contribution of Working Group I to the Fifth Assessment Report of the Intergovernmental Panel on Climate Change, Cambridge University Press, Cambridge, United Kingdom and New York, NY, USA, 2013.

Ito, A. and Inatomi, M.: Use of a process-based model for assessing the methane budgets of global terrestrial ecosystems and evaluation of uncertainty, Biogeosciences, 9, 759-773, doi:10.5194/bg9-759-2012, 2012.

Jennifer, D. W., John, S. K., Annett, B., and Kyle, C. M.: Surface water inundation in the boreal-Arctic: potential impacts on regional methane emissions, Environ. Res. Lett., 9, 075001, doi:10.1088/1748-9326/9/7/075001, 2014.

Junk, W., Piedade, M., Schöngart, J., Cohn-Haft, M., Adeney, J. M., and Wittmann, F.: A Classification of Major Naturally-Occurring Amazonian Lowland Wetlands, Wetlands, 31, 623-640, 2011.

Kaplan, J. O.: Wetlands at the Last Glacial Maximum: Distribution and methane emissions, Geophys. Res. Lett., 29, 3-1-3-4, 2002.

Kerr, Y. H., Waldteufel, P., Wigneron, J. P., Delwart, S., Cabot, F., Boutin, J., Escorihuela, M. J., Font, J., Reul, N., Gruhier, C., Juglea, S. E., Drinkwater, M. R., Hahne, A., Martin-Neira, M., and Mecklenburg, S.: The SMOS Mission: New Tool for Monitoring Key Elements ofthe Global Water Cycle, P. IEEE, 98, 666-687, 2010.

Kim, Y., Kimball, J. S., Zhang, K., and McDonald, K. C.: Satellite detection of increasing Northern Hemisphere non-frozen seasons from 1979 to 2008: Implications for regional vegetation growth, Remote Sens. Environ., 121, 472-487, 2012.

Kirschke, S., Bousquet, P., Ciais, P., Saunois, M., Canadell, J. G., Dlugokencky, E. J., Bergamaschi, P., Bergmann, D., Blake, D. R., Bruhwiler, L., Cameron-Smith, P., Castaldi, S., Chevallier, F., Feng, L., Fraser, A., Heimann, M., Hodson, E. L., Houweling, S., Josse, B., Fraser, P. J., Krummel, P. B., Lamarque, J.-F., Langenfelds, R. L., Le Quere, C., Naik, V., O’Doherty, S., Palmer, P. I., Pison, I., Plummer, D., Poulter, B., Prinn, R. G., Rigby, M., Ringeval, B., Santini, M., Schmidt, M., Shindell, D. T., Simpson, I. J., Spahni, R., Steele, L. P., Strode, S. A., Sudo, K., Szopa, S., van der Werf, G. R., Voulgarakis, A., van Weele, M., Weiss, R. F., Williams, J. E., and Zeng, G.: Three decades of global methane sources and sinks, Nat. Geosci., 6, 813-823, 2013.

Kleinen, T., Brovkin, V., and Schuldt, R. J.: A dynamic model of wetland extent and peat accumulation: results for the Holocene, Biogeosciences, 9, 235-248, doi:10.5194/bg-9-235-2012, 2012.

Kopecký, M. and Č́ižková, Š.: Using topographic wetness index in vegetation ecology: does the algorithm matter?, Appl. Veg. Sci., $13,450-459,2010$. 
Leff, B., Ramankutty, N., and Foley, J. A.: Geographic distribution of major crops across the world, Global Biogeochem. Cy., 18, GB1009, doi:10.1029/2003GB002108, 2004.

Lehner, B. and Döll, P.: Development and validation of a global database of lakes, reservoirs and wetlands, J. Hydrol., 296, 1-22, 2004.

Lehner, B. and Grill, G.: Global river hydrography and network routing: baseline data and new approaches to study the world's large river systems, Hydrol. Process., 27, 2171-2186, 2013.

Lehner, B., Verdin, K., and Jarvis, A.: New Global Hydrography Derived From Spaceborne Elevation Data, Eos, Transactions American Geophysical Union, 89, 93-94, 2008.

Lei, H., Huang, M., Leung, L. R., Yang, D., Shi, X., Mao, J., Hayes, D. J., Schwalm, C. R., Wei, Y., and Liu, S.: Sensitivity of global terrestrial gross primary production to hydrologic states simulated by the Community Land Model using two runoff parameterizations, Journal of Advances in Modeling Earth Systems, 6, 658-679, 2014.

Liang, X., Lettenmaier, D. P., Wood, E. F., and Burges, S. J.: A simple hydrologically based model of land surface water and energy fluxes for general circulation models, J. Geophys. Res.-Atmos., 99, 14415-14428, 1994.

Lin, K., Zhang, Q., and Chen, X.: An evaluation of impacts of DEM resolution and parameter correlation on TOPMODEL modeling uncertainty, J. Hydrol., 394, 370-383, 2010.

Lin, S., Jing, C., Coles, N., Chaplot, V., Moore, N., and Wu, J.: Evaluating DEM source and resolution uncertainties in the Soil and Water Assessment Tool, Stoch. Environ. Res. Risk Assess., 27, 209-221, 2013.

Marthews, T. R., Quesada, C. A., Galbraith, D. R., Malhi, Y., Mullins, C. E., Hodnett, M. G., and Dharssi, I.: High-resolution hydraulic parameter maps for surface soils in tropical South America, Geosci. Model Dev., 7, 711-723, doi:10.5194/gmd-7711-2014, 2014.

Marthews, T. R., Dadson, S. J., Lehner, B., Abele, S., and Gedney, N.: High-resolution global topographic index values for use in large-scale hydrological modelling, Hydrol. Earth Syst. Sci., 19, 91-104, doi:10.5194/hess-19-91-2015, 2015.

Matthews, E. and Fung, I.: Methane emission from natural wetlands: Global distribution, area, and environmental characteristics of sources, Global Biogeochem. Cy., 1, 61-86, 1987.

Melack, J. M., Hess, L. L., Gastil, M., Forsberg, B. R., Hamilton, S. K., Lima, I. B. T., and Novo, E. M. L. M.: Regionalization of methane emissions in the Amazon Basin with microwave remote sensing, Glob. Change Biol., 10, 530-544, 2004.

Melton, J. R., Wania, R., Hodson, E. L., Poulter, B., Ringeval, B., Spahni, R., Bohn, T., Avis, C. A., Beerling, D. J., Chen, G., Eliseev, A. V., Denisov, S. N., Hopcroft, P. O., Lettenmaier, D. P., Riley, W. J., Singarayer, J. S., Subin, Z. M., Tian, H., Zürcher, S., Brovkin, V., van Bodegom, P. M., Kleinen, T., Yu, Z. C., and Kaplan, J. O.: Present state of global wetland extent and wetland methane modelling: conclusions from a model intercomparison project (WETCHIMP), Biogeosciences, 10, 753788, doi:10.5194/bg-10-753-2013, 2013.

Meng, L., Hess, P. G. M., Mahowald, N. M., Yavitt, J. B., Riley, W. J., Subin, Z. M., Lawrence, D. M., Swenson, S. C., Jauhiainen, J., and Fuka, D. R.: Sensitivity of wetland methane emissions to model assumptions: application and model testing against site observations, Biogeosciences, 9, 2793-2819, doi:10.5194/bg-92793-2012, 2012.

Mulligan, M. and Wainwright, J.: Modelling and Model Building, in: Environmental Modelling, John Wiley \& Sons, Ltd, Chichester, UK, 7-26, 2013.

Nachtergaele, F., Van Velthuizen, H., Verelst, L., Batjes, N., Dijkshoorn, K., Van Engelen, V., Fischer, G., Jones, A., Montanarella, L., and Petri, M.: Harmonized world soil database, FAO, Rome, Italy and IIASA, Laxenburg, Austria, 2008.

National Wetland Working Group: Wetlands of Canada, Ecolgoical Land Classification Series, No. 24, Canada Committee on Ecological Land Classification, Sustainable Development Branch, Environment Canada and Polyscience Publications Inc, Montreal, Quebec, Canada, 1997.

Nisbet, E. G., Dlugokencky, E. J., and Bousquet, P.: Methane on the Rise-Again, Science, 343, 493-495, 2014.

Niu, G.-Y., Yang, Z.-L., Dickinson, R. E., and Gulden, L. E.: A simple TOPMODEL-based runoff parameterization (SIMTOP) for use in global climate models, J. Geophys. Res.-Atmos., 110, D21106, doi:10.1029/2005JD006111, 2005.

Pan, F., Peters-Lidard, C. D., Sale, M. J., and King, A. W.: A comparison of geographical information systems-based algorithms for computing the TOPMODEL topographic index, Water Resour. Res., 40, W06303, doi:10.1029/2004WR003069, 2004.

Papa, F., Prigent, C., Aires, F., Jimenez, C., Rossow, W. B., and Matthews, E.: Interannual variability of surface water extent at the global scale, 1993-2004, J. Geophys. Res.-Atmos., 115, D12111, doi:10.1029/2009JD012674, 2010.

Peregon, A., Maksyutov, S., Kosykh, N. P., and MironychevaTokareva, N. P.: Map-based inventory of wetland biomass and net primary production in western Siberia, J. Geophys. Res.-Biogeo., 113, G01007, doi:10.1029/2007JG000441, 2008.

Petrescu, A. M. R., van Beek, L. P. H., van Huissteden, J., Prigent, C., Sachs, T., Corradi, C. A. R., Parmentier, F. J. W., and Dolman, A. J.: Modeling regional to global $\mathrm{CH}_{4}$ emissions of boreal and arctic wetlands, Global Biogeochem. Cy., 24, GB4009, doi:10.1029/2009GB003610, 2010.

Petrescu, A. M. R., Lohila, A., Tuovinen, J.-P., Baldocchi, D. D., Desai, A. R., Roulet, N. T., Vesala, T., Dolman, A. J., Oechel, W. C., Marcolla, B., Friborg, T., Rinne, J., Matthes, J. H., Merbold, L., Meijide, A., Kiely, G., Sottocornola, M., Sachs, T., Zona, D., Varlagin, A., Lai, D. Y. F., Veenendaal, E., Parmentier, F.-J. W., Skiba, U., Lund, M., Hensen, A., van Huissteden, J., Flanagan, L. B., Shurpali, N. J., Grünwald, T., Humphreys, E. R., JackowiczKorczyński, M., Aurela, M. A., Laurila, T., Grüning, C., Corradi, C. A. R., Schrier-Uijl, A. P., Christensen, T. R., Tamstorf, M. P., Mastepanov, M., Martikainen, P. J., Verma, S. B., Bernhofer, C., and Cescatti, A.: The uncertain climate footprint of wetlands under human pressure, P. Natl. Acad. Sci. USA, 112, 4594-4599, 2015.

Poulter, B., Ciais, P., Hodson, E., Lischke, H., Maignan, F., Plummer, S., and Zimmermann, N. E.: Plant functional type mapping for earth system models, Geosci. Model Dev., 4, 993-1010, doi:10.5194/gmd-4-993-2011, 2011.

Poulter, B., Bousquet, P., Canadell, P., Ciais, P., Peregon, A., Arora, V., Beerling, D., Brovkin, V., Hopcroft, P., Jones, C., Joos, F., Gedney, N., Ito, A., Kleinen, T., Koven, C., MacDonald, K., Melton, J., Peng, C., Peng, S., Schroder, R., Prigent, C., Riley, B., Saito, M., Spahni, R., Tian, H., Taylor, L., Viovy, N., Wilton, 
D., Wiltshire, A., Xu, X., and Zhang, Z.,: Global wetland contribution to increasing atmospheric methane concentrations (20002012), in preparation, 2015.

Prigent, C., Papa, F., Aires, F., Rossow, W. B., and Matthews, E.: Global inundation dynamics inferred from multiple satellite observations, 1993-2000, J. Geophys. Res.-Atmos., 112, D12107, doi:10.1029/2006JD007847, 2007.

Prigent, C., Papa, F., Aires, F., Jimenez, C., Rossow, W. B., and Matthews, E.: Changes in land surface water dynamics since the 1990 s and relation to population pressure, Geophys. Res. Lett., 39, L08403, doi:10.1029/2012GL051276, 2012.

Quinn, P. F., Beven, K. J., and Lamb, R.: The in $(\mathrm{a} / \mathrm{tan} / \beta)$ index: How to calculate it and how to use it within the topmodel framework, Hydrol. Process., 9, 161-182, 1995.

Quiquet, A., Archibald, A. T., Friend, A. D., Chappellaz, J., Levine, J. G., Stone, E. J., Telford, P. J., and Pyle, J. A.: The relative importance of methane sources and sinks over the Last Interglacial period and into the last glaciation, Quaternary Sci. Rev., 112, 116, 2015.

Ringeval, B., Decharme, B., Piao, S. L., Ciais, P., Papa, F., de Noblet-Ducoudré, N., Prigent, C., Friedlingstein, P., Gouttevin, I., Koven, C., and Ducharne, A.: Modelling sub-grid wetland in the ORCHIDEE global land surface model: evaluation against river discharges and remotely sensed data, Geosci. Model Dev., 5, 941-962, doi:10.5194/gmd-5-941-2012, 2012.

Ringeval, B., Houweling, S., van Bodegom, P. M., Spahni, R., van Beek, R., Joos, F., and Röckmann, T.: Methane emissions from floodplains in the Amazon Basin: challenges in developing a process-based model for global applications, Biogeosciences, 11, 1519-1558, doi:10.5194/bg-11-1519-2014, 2014.

Rinne, J., Riutta, T., Pihlatie, M., Aurela, M., Haapanala, S., Tuovinen, J.-P., Tuittila, E.-S., and Vesala, T.: Annual cycle of methane emission from a boreal fen measured by the eddy covariance technique, Tellus B, 59, 449-457, 2007.

Schroeder, R., McDonald, K., Chan, S., Chapman, B., Podest, E., Bohn, T., Jones, L., Kimball, J., Zimmermann, R., and Küppers, M.: Development and evaluation of a multi-year global inundated area dataset derived from combined active/passive microwave remote sensing, in preparation, 2016.

Seneviratne, S. I., Corti, T., Davin, E. L., Hirschi, M., Jaeger, E. B., Lehner, I., Orlowsky, B., and Teuling, A. J.: Investigating soil moisture-climate interactions in a changing climate: A review, Earth-Sci. Rev., 99, 125-161, 2010.

Sheng, Y., Smith, L. C., MacDonald, G. M., Kremenetski, K. V., Frey, K. E., Velichko, A. A., Lee, M., Beilman, D. W., and Dubinin, P.: A high-resolution GIS-based inventory of the west Siberian peat carbon pool, Global Biogeochem. Cy., 18, GB3004, doi:10.1029/2003GB002190, 2004.

Singarayer, J. S., Valdes, P. J., Friedlingstein, P., Nelson, S., and Beerling, D. J.: Late Holocene methane rise caused by orbitally controlled increase in tropical sources, Nature, 470, 82-85, 2011.

Sitch, S., Smith, B., Prentice, I. C., Arneth, A., Bondeau, A., Cramer, W., Kaplan, J. O., Levis, S., Lucht, W., Sykes, M. T., Thonicke, K., and Venevsky, S.: Evaluation of ecosystem dynamics, plant geography and terrestrial carbon cycling in the LPJ dynamic global vegetation model, Glob. Change Biol., 9, 161-185, 2003.
Sivapalan, M., Beven, K., and Wood, E. F.: On hydrologic similarity: 2. A scaled model of storm runoff production, Water Resour. Res., 23, 2266-2278, 1987.

Sørensen, R. and Seibert, J.: Effects of DEM resolution on the calculation of topographical indices: TWI and its components, J. Hydrol., 347, 79-89, 2007.

Spahni, R., Wania, R., Neef, L., van Weele, M., Pison, I., Bousquet, P., Frankenberg, C., Foster, P. N., Joos, F., Prentice, I. C., and van Velthoven, P.: Constraining global methane emissions and uptake by ecosystems, Biogeosciences, 8, 1643-1665, doi:10.5194/bg8-1643-2011, 2011.

Stieglitz, M., Rind, D., Famiglietti, J., and Rosenzweig, C.: An Efficient Approach to Modeling the Topographic Control of Surface Hydrology for Regional and Global Climate Modeling, J. Climate, 10, 118-137, 1997.

Stocker, B. D., Roth, R., Joos, F., Spahni, R., Steinacher, M., Zaehle, S., Bouwman, L., Xu, R., and Prentice, I. C.: Multiple greenhouse-gas feedbacks from the land biosphere under future climate change scenarios, Nature Climate Change, 3, 666-672, 2013.

Stocker, B. D., Spahni, R., and Joos, F.: DYPTOP: a costefficient TOPMODEL implementation to simulate sub-grid spatio-temporal dynamics of global wetlands and peatlands, Geosci. Model Dev., 7, 3089-3110, doi:10.5194/gmd-7-30892014, 2014.

Tarnocai, C., Canadell, J. G., Schuur, E. A. G., Kuhry, P., Mazhitova, G., and Zimov, S.: Soil organic carbon pools in the northern circumpolar permafrost region, Global Biogeochem. Cy., 23, GB2023, doi:10.1029/2008GB003327, 2009.

Turetsky, M. R., Kotowska, A., Bubier, J., Dise, N. B., Crill, P., Hornibrook, E. R. C., Minkkinen, K., Moore, T. R., MyersSmith, I. H., Nykänen, H., Olefeldt, D., Rinne, J., Saarnio, S., Shurpali, N., Tuittila, E.-S., Waddington, J. M., White, J. R., Wickland, K. P., and Wilmking, M.: A synthesis of methane emissions from 71 northern, temperate, and subtropical wetlands, Glob. Change Biol., 20, 2183-2197, 2014.

USGS: HYDRO1k Elevation Derivative Database, US Geological Survey Earth Resources Observation and Science (EROS) Data Center (EDC), Sioux Falls, South Dakota, USA, 1996.

Verpoorter, C., Kutser, T., Seekell, D. A., and Tranvik, L. J.: A global inventory of lakes based on high-resolution satellite imagery, Geophys. Res. Lett., 41, 6396-6402, 2014.

Wania, R., Ross, I., and Prentice, I. C.: Integrating peatlands and permafrost into a dynamic global vegetation model: 1 . Evaluation and sensitivity of physical land surface processes, Global Biogeochem. Cy., 23, GB3014, doi:10.1029/2008GB003412, 2009.

Wania, R., Melton, J. R., Hodson, E. L., Poulter, B., Ringeval, B., Spahni, R., Bohn, T., Avis, C. A., Chen, G., Eliseev, A. V., Hopcroft, P. O., Riley, W. J., Subin, Z. M., Tian, H., van Bodegom, P. M., Kleinen, T., Yu, Z. C., Singarayer, J. S., Zürcher, S., Lettenmaier, D. P., Beerling, D. J., Denisov, S. N., Prigent, C., Papa, F., and Kaplan, J. O.: Present state of global wetland extent and wetland methane modelling: methodology of a model inter-comparison project (WETCHIMP), Geosci. Model Dev., 6, 617-641, doi:10.5194/gmd-6-617-2013, 2013.

Ward, R. C. and Robinson, M.: Principles of Hydrology, 4th Edn, McGraw-Hill, Maidenhead, UK, 2000. 
Whalen, S. C. and Reeburgh, W. S.: Interannual variations in tundra methane emission: A 4-year time series at fixed sites, Global Biogeochem. Cy., 6, 139-159, 1992.

Wilson, J. P. and Gallant, J. C.: Terrain analysis: principles and applications, John Wiley \& Sons, New York, NY, USA, 2000.

Wood, E. F., Roundy, J. K., Troy, T. J., van Beek, L. P. H., Bierkens, M. F. P., Blyth, E., de Roo, A., Döll, P., Ek, M., Famiglietti, J., Gochis, D., van de Giesen, N., Houser, P., Jaffé, P. R., Kollet, S., Lehner, B., Lettenmaier, D. P., Peters-Lidard, C., Sivapalan, M., Sheffield, J., Wade, A., and Whitehead, P.: Hyperresolution global land surface modeling: Meeting a grand challenge for monitoring Earth's terrestrial water, Water Resour. Res., 47, W05301, doi:10.1029/2010WR010090, 2011.

Woodward, C., Shulmeister, J., Larsen, J., Jacobsen, G. E., and Zawadzki, A.: The hydrological legacy of deforestation on global wetlands, Science, 346, 844-847, 2014.

Zhang, Z., Jiang, H., Liu, J., Ju, W., and Zhang, X.: Effect of heterogeneous atmospheric $\mathrm{CO}_{2}$ on simulated global carbon budget, Global Planet. Change, 101, 33-51, 2013.

Zhu, X., Zhuang, Q., Lu, X., and Song, L.: Spatial scale-dependent land-atmospheric methane exchanges in the northern high latitudes from 1993 to 2004, Biogeosciences, 11, 1693-1704, doi:10.5194/bg-11-1693-2014, 2014.
Zhu, Q., Peng, C., Chen, H., Fang, X., Liu, J., Jiang, H., Yang, Y., and Yang, G.: Estimating global natural wetland methane emissions using process modelling: spatio-temporal patterns and contributions to atmospheric methane fluctuations, Global Ecol. Biogeogr., 24, 959-972, doi:10.1111/geb.12307, 2015.

Zhuang, Q., Melillo, J. M., Kicklighter, D. W., Prinn, R. G., McGuire, A. D., Steudler, P. A., Felzer, B. S., and $\mathrm{Hu}$, S.: Methane fluxes between terrestrial ecosystems and the atmosphere at northern high latitudes during the past century: A retrospective analysis with a process-based biogeochemistry model, Global Biogeochem. Cy., 18, GB3010, doi:10.1029/2004GB002239, 2004.

Zona, D., Oechel, W. C., Kochendorfer, J., Paw, U. K. T., Salyuk, A. N., Olivas, P. C., Oberbauer, S. F., and Lipson, D. A.: Methane fluxes during the initiation of a large-scale water table manipulation experiment in the Alaskan Arctic tundra, Global Biogeochem. Cy., 23, GB2013, doi:10.1029/2009GB003487, 2009.

Zürcher, S., Spahni, R., Joos, F., Steinacher, M., and Fischer, H.: Impact of an abrupt cooling event on interglacial methane emissions in northern peatlands, Biogeosciences, 10, 1963-1981, doi:10.5194/bg-10-1963-2013, 2013. 